\title{
HAZARDOUS SUBSTANCES IN THE WORKPLAGE: IMPLICATIONS FOR THE EMPLOYMENT RIGHTS OF WOMEN
}

\author{
LINDA G. HowARD †
}

In recent years, awareness of the health risks from chemicals in the workplace has increased dramatically. ${ }^{1}$ The possibility that occupational exposure to some chemicals can affect a worker's ability to produce normal children has received particular attention. ${ }^{2}$ In response, many American companies have removed women with childbearing capacity from their jobs and refused to hire women with childbearing capacity. ${ }^{3}$ These employers assert that their purpose is to protect women workers and their offspring from birth defects, miscarriages, and stillbirths-all misfortunes that may result from workplace exposure to hazardous chemicals.*

Employment policies that exclude women solely because they may become pregnant are clear violations of the 1978 "pregnancy amendment" to title VII of the Civil Rights Act of 1964,5 which prohibits discrimination in employment on the basis of pregnancy,

I Associate Professor of Law, Ohio State University. B.A. 1971, Reed College; J.D. 1973, University of Virginia. Member, Virginia Bar.

1 See generally H.R. Rer. No. 1341, 94th Cong., 2d Sess. 3 (1976).

2 See, e.g., Brody, Sperm Found Especially Vulnerable to Environment, N.Y. Times, Mar. 10, 1981, at Cl, col. 5; Hricko, Social Policy Considerations of Occupational Health Standards: The Example of Lead and Reproductive Effects, 7 Preventive Med. 398 (1978); Hyatt, Early Warning Protection for the Unborn? Work Safety Issue Isn't As Simple As It Sounds, Wall St. J., Aug. 2, 1977, at 1, col. I; Trebilcock, OSHA and Equal Employment Opportunity Laws for Women, 7 Preventrve Med. 372 (1978).

3 It is instructive to note that traditionally male-dominated industries have demonstrated concern for pregnancy outcomes by excluding fertile women. Companies that require proof from female applicants and employees of inability to bear children include American Cyanamid Company, Dow Chemical Company, General Motors Corporation (Delco-Remy Division), Monsanto, Firestone, B.F. Goodrich, and St. Joe Minerals Corporation. Hricko, supra note 2, at 398-99. Exclusionary policies have not been adopted by American employers in female-dominated industries, such as agriculture and textiles, in which substantial numbers of female workers are exposed to similarly hazardous substances, including pesticides and certain hydrocarbons. See note 40 infra \& accompanying text. 1979).

${ }^{4}$ See, e.g., Doerr v. B.F. Goodrich Co., 484 F. Supp. 320, 321 (N.D. Ohio

542 U.S.C. $\$ 2000 \mathrm{e}(\mathrm{k})$ (Supp. III 1979). 
childbirth, or related medical conditions. ${ }^{6}$ Some policies may also violate the Occupational Safety and Health Act of $1970^{7}$ (OSH Act), which mandates a safe and healthful work environment for all employees. ${ }^{8}$ Neither the OSH Act nor title VII, however, satisfactorily resolves the question when, if ever, an employer may exclude employees who are endangered by the work environment.

In an attempt to address the issue, the Equal Employment Opportunity Commission (EEOC), the Occupational Safety and Health Administration (OSHA), and the Office of Federal Contract Compliance Programs (OFCCP) jointly issued "Proposed Interpretive Guidelines on Employment Discrimination and Hazardous Substances," " but withdrew them in early 1981.10 The failure of

- See notes 88-97 infra \& accompanying text.

729 U.S.C. $\$ \$ 651-678$ (1976, Supp. II 1978 \& Supp. III 1979).

8 See notes 44-66 infra \& accompanying text.

945 Fed. Reg. 7514 (1980), corrected in 45 Fed. Reg. 16,501 (1980) [hereinafter cited as Guidelines].

The proposed guidelines were prompted by the discovery that several employers had adopted the practice of excluding pregnant and fertile women from employment in apparent violation of the newly enacted "pregnancy amendment" to title VII, 42 U.S.C. $\$ 2000 \mathrm{e}(\mathrm{k})$ (Supp. III 1979). 45 Fed. Reg. 7514 (1980). The EEOC recognized that the real issue was much broader than the employment rights of fertile or pregnant women. The ultimate question was whether the employer had fulfilled its duty to maintain a safe working environment for all of its workers. In an admirable and relatively unusual spirit of inter-agency cooperation, the EEOC, OSHA, and OFCCP embarked upon a joint project to resolve the problem.

Neither an application of current law nor a proposal for change, the guidelines are best described as a road map designed to lead the federal courts through the relevant issues to an accommodating modification in title VII law. Thus, though they have now been withdrawn, see note 10 infra, the guidelines are worthy of careful consideration. See notes 204,213 \& 217-18 infra.

The guidelines proposed consideration of at least nine factors in determining whether an employer's exclusionary policy was nondiscriminatory or justified: (1) whether the policy has been applied consistently to both sexes; (2) whether the employer has complied with applicable occupational safety and health laws; (3) whether the employer has investigated the effects of all scientifically recognized reproductive hazards in the workplace on those adversely affected and those not similarly affected; (4) whether the hazard is significantly greater for or confined to the excluded group; (5) whether the employer has a pattern of discrimination against the excluded group; (6) whether the policy is narrowly tailored to the type of hazard posed; (7) whether there is no evidence that the hazard poses a significant health risk to body systems other than the reproductive system for the class not excluded; (8) whether the employer has investigated alternatives to exclusion, and (9) whether the employer is monitoring scientific developments. 45 Fed. Reg. at 7515.

The proposal offered in this Article differs from the guidelines both in style and substance. In most applications, however, the proposal is consistent with the EEOC's guidelines.

1046 Fed. Reg. 3916 (1981):

Extensive comments were received. Upon reviewing the comments, the agencies have concluded that the most appropriate method of eliminating employment discrimination in the work place where there is potential 
this initial administrative attempt to solve the problem of fetal health in the workplace ${ }^{11}$ leaves the federal courts with no clear guidance as to how to treat discrimination based on childbearing age or capacity under title VII.

The paramount problem is that, while under existing title VII law an employer may not exclude a woman from employment because she has childbearing capacity or is of childbearing age, in some circumstances exclusion may be the only feasible means to protect fetal health. ${ }^{12}$ A significant underlying problem is that fetal injury from occupational exposure to hazardous substances is generally associated with exposure of women workers, although there is substantial evidence that males are also affected by reproductively toxic chemicals. ${ }^{13}$

The issues are easily resolved in cases in which employers are able to protect workers from reproductive injury without excluding susceptible employees, or when the OSH Act imposes a duty to remove the hazard from the workplace rather than remove the employee. That Act requires the employer to provide a safe workplace only if it is "feasible" for the employer's industry to do so. ${ }^{14}$

exposure to reproductive hazards is through investigation and enforcement of the law on a case by case basis, rather than by the issuance of interpretive guidelines.

11 Judicial and quasi-judicial attempts at resolving this question have been no more fruitful. After several women employees of American Cyanamid Company underwent sterilization in order to keep their jobs in the company's lead pigments division, OSHA issued a citation challenging their employer's "fetus protection policy." The employer sought review before the Occupational Safety and Health Review Commission. See note 57 infra. The challenge was dismissed on the employer's motion for summary judgment. Secretary of Labor v. American Cyanamid Co., OSHRC Docket No. 79-5762 (July 15, 1980), discussed further at text accompanying notes 241-54 infra. Litigation in this case is also pending in the federal courts. See Christman v. American Cyanamid Co., No. 80-0024-P (N.D. W. Va., filed May 20, 1980).

The similar policy adopted by B.F. Goodrich has sustained attack in the federal courts. In Doerr v. B.F. Goodrich Co., 484 F. Supp. 320 (N.D. Ohio 1979), the district court denied a request for a preliminary injunction brought by a female employee who was excluded from working in the company's vinyl chloride polymerization plant. The employer did not, however, terminate her completely; rather, she was transferred to a lower level position without loss of pay. Id. 321, 325. This was enough to permit the court to sidestep the issue whether the employer's policy survived scrutiny under title VII by deciding that the plaintiff had not demonstrated irreparable injury. See id. 323. The court stated in dictum, however, that it considered the plaintiff unlikely to succeed on the merits. Id. 326.

12 See text accompanying notes 167-68 infra.

13 See text accompanying notes $23,32-34$ \& 39 infra.

${ }^{14}$ See note 47 infra. 
When other nondiscriminatory protective measures are not feasible, however, the interests in fetal health and the worker's right to be free from discrimination on the basis of sex are in conflict.

The potential for fetal harm from workplace chemicals imposes hard choices among competing societal interests. The important societal interest in the worker's reproductive health, the national policy of equal employment opportunity, and the employer's legitimate interest in business profitability all must be considered. The purpose of this Article is to analyze the issues raised by exclusionary employment policies, to define the duties imposed under title VII and the OSH Act on the employer who seeks to protect the unborn from the hazards of workplace toxins, and to propose a workable resolution of the conflict between the health of the unborn and the employment rights of working women. 15

The analysis begins in part I with a description of the chemicals and the industries involved and a summary of the medical data establishing the health risks of occupational exposure to workplace toxins, particularly reproductive risks. Part II outlines the scope of the legal issues and develops the policies served by the OSH Act. Part III analyzes title VII's prohibition against sex discrimination and applies title VII to policies that exclude on the basis of childbearing age and capacity. The existing title VII defenses are then analyzed and applied as the final step in determining the lawfulness of exclusion on the basis of childbearing age or capacity. Part IV discusses the problems inherent in current title VII analysis, and demonstrates the need for reform. Part $\mathrm{V}$ proposes changing title VII law through judicial interpretation to permit the employer to exclude susceptible workers in the limited circumstances in which exclusion is necessary to protect fetal health. The Article concludes that a modification in title VII law through the judicial process, rather than legislative amendment, is the best solution to the problem of discriminatory practices resulting from occupational exposure to hazardous substances.

15 For other scholarly discussions and attempts to resolve this problem, see Finneran, Title VII and Restrictions on Employment of Fertile Women, 31 LAB. L.J. 223 (1980); Furnish, Prenatal Exposure to Fetally Toxic Work Environments: The Dilemma of the 1978 Pregnancy Amendment to Title VII of the Civil Rights Act of 1964, 66 Iows L. Rev. 63 (1980); Comment, Employment Rights of Women in the Toxic Workplace, 65 CALIF. L. Rev. 1113 (1977) [hereinafter cited as Carrf. Comment]; Note, Exclusionary Employment Practices in Hazardous Industries: Protection or Discrimination?, 5 ColuM. J. ENv''L L. 97 (1978) [hereinafter cited as CoLUM. Note]; Note, Birth Defects Caused by Parental Exposure to Workplace Hazards: The Interface of Title VII with OSHA and Tort Law, 12 U. MícE. J.L. ReF. 237 (1979) [hereinafter cited as Mrce. Note]. 


\section{Health Effects of Toxic Substances on the Human Reproductive System}

When the employer excludes fertile women from employment because of the possible adverse health effects of toxic substances in the workplace, consideration of the toxin's effects on the general health and reproductive processes of both male and female workers will in large part dictate whether the policy violates title VII. Clearly, if the substance harms both men and women (or their offspring), any policy that excludes only women discriminates on the basis of sex. An examination of the available scientific data-and, perhaps even more important, an appreciation for the glaring deficiencies in the available data-is, therefore, the first step in resolving the issue.

Although the precise manner in which many chemicals affect the workers' reproductive systems is unknown, ${ }^{16}$ medical researchers have established relationships between occupational exposure to certain chemicals and observable physiological symptoms. A short discussion of these relationships is in order. ${ }^{17}$ Toxic substances may harm the fetus either indirectly, by altering the parent's reproductive system, or directly, by attacking the embryo or fetus itself. Gametotoxins cause malformations of the egg or sperm prior to conception. ${ }^{18}$ Mutagens alter the chromosomal structure of the parental germ plasm. ${ }^{19}$ Teratogens operate directly on the developing embryo or fetus. ${ }^{20}$ A given substance may have gametotoxic, mutagenic, and teratogenic effects depending upon both the nature of the substance and the level of exposure.

${ }^{16}$ Most chemicals have not been tested for their effects on human reproduction. J. Stelrman, Women's Work, Women's Health: MYtris and REArities 156 (1977). The Chemical Abstract Service listed over 4 million distinct chemical entities as of November 1977, of which 33,000 are in common use. Maugh, Chemicals: How Many Are There? 199 Scrence 162 (1978). For a discussion of methodology and a summary of clinical findings, see Manson, Human and Laboratory Animal Test Systems Available for Detection of Reproductive Failure, 7 Preventrve Med. 322, 325-27 (1978).

${ }^{17}$ For a more complete summary of this subject, see Furnish, supra note 15, at 119-29.

18 CalrF. Comment, supra note 15, at 1116.

19 Id. See Strobino, Kline \& Stein, Chemical and Physical Exposures of Parents: Effects on Human Reproduction and Offspring, 1 EaruY HuMan Dev. 371,375 (1978).

20 Carm. Comment, supra note 15, at 1116 \& n.13. See Manson, supra note 16 , at $325-29$. 


\section{A. Lead}

Lead is one of the few toxins whose harmful effects to employees are well-documented. ${ }^{21}$ Occupational exposure to lead can impair the respiratory, cardiovascular, renal, and reproductive systems. ${ }^{22}$ It is important to note that, even in the reproductive area, lead harms both male and female workers. In males, there is evidence of decreased sexual drive, impotence, sterility, and decreased ability to produce normal sperm, ${ }^{23}$ which leads to abnormal pregnancies in their mates.24 Occupational exposure of females to lead can cause sterility, abnormal ovarian cycles, menstrual disorders, premature birth, miscarriage, and stillbirth. ${ }^{25}$

The ability of lead to damage the developing embryo or fetus suggests that lead acts as a teratogen. ${ }^{26}$ Exposure of mothers to high concentrations of lead during pregnancy has been linked with mental retardation ${ }^{27}$ and neurological disorders ${ }^{28}$ in their offspring. The substance is also suspected of having mutagenic and gametotoxic effects. ${ }^{29}$

\section{B. Vinyl Chloride and Chloroprene}

Workers exposed to vinyl chloride and its sister chemical, chloroprene, used in the manufacture of vinyls, plastics, and syn-

21 See 29 C.F.R. $\$ 1910.1025$ (1980) (OSHA lead standards); 43 Fed. Reg. 52,954-63 (1978); Furnish, supra note 15, at 70-74.

$22 \mathrm{See} 43$ Fed. Reg. 52,854-63 (1978); Bridbord, Occupational Lead Exposure and Women, 7 Preventive Med. 311 (1978). See generally Comartrtes on liead in the Human Environment, National Research Councit, Lead IN THE Human ENVIRONMENT (1980) [hereinafter cited as LEAd IN THE HUMaAN ENVIRONMENT].

${ }^{23}$ See 29 C.F.R. $\$ 1910.1025$, app. A (1980) (substance data sheet for overexposure to lead); 43 Fed. Reg. 52,959 (1978); LEAD IN THE HUMAN ENvIRONMENT, supra note 22, at 7; A. HRTCKO \& M. BRUNT, WORKTNG YOR YOUR LIFE: A Woman's Gutoe to Job Healtie Hazards C-6 (1976).

2429 C.F.R. $\$ 1910.1025$, app. A (1980); Infante \& Wagoner, The Effects of Lead on Reproduction, in SOcIETY FOR OccupatToNat AND ENVIRONMENTAL Healtr, Proceemings, Conference on Women and the Workplace 232-43 (1977) [hereinafter cited as SOEH CONFERENCE]; Rom, Effects of Lead on the Female and Reproduction: A Review, 43 MT. Sinar J. Med. 542, 546 (1976).

2529 C.F.R. $\$ 1910.1025$, app. A (1980); 43 Fed. Reg. 52,959 (1978); Lead in the Human ENvironment, supta note 22, at 7; A. Hricko \& M. Brunt, supra note 23 , at C-7, C-8.

20 Bridbord, supra note 22 , at 313.

27 Id. 317; Timpo, Amin, Casalino \& Yuceoglu, Congenital Lead Intoxication, 94 J. Pediatrics 765, 766 (1979).

28 Rom, supra note 24, at 545; Timpo, Amin, Casalino \& Yuceoglu, supra note 27 , at 766 .

${ }^{29}$ See 43 Fed. Reg. 52,959 (1978); Hricko, swpre note 2, at 396; Calar. Comment, supra note 15, at 1120 n.25. 
thetic rubbers, risk severe impairment to their health in general ${ }^{30}$ and to their reproductive systems in particular..$^{31}$ Wives of male workers occupationally exposed to vinyl chloride experience a significantly higher than normal rate of fetal deaths. ${ }^{32}$ Abnormal numbers of chromosomal aberrations in males who work with vinyl chloride lead medical experts to conclude that occupational exposure causes germ cell damage in the father. ${ }^{33}$ Children of male vinyl chloride workers and even children born in communities near vinyl chloride processing facilities have an increased incidence of congenital birth defects..$^{34}$

Chloroprene, a chemical compound structurally similar to vinyl chloride, is used widely in the chemical industry to produce the rubber substitute, polychloroprene. Studies reveal that males occupationally exposed to chloroprene suffer decreased motility of sperm. ${ }^{35}$ Other studies report that wives of workers exposed to chloroprene suffered three times the expected number of miscar-

30 See generally Anderson, Snyder, Lewinson, Woo, Lilis \& Selikoff, Levels of CEA Among Vinyl Chloride and Polyvinyl Chloride Exposed Workers, 42 CaNCER 1560 (1978); Wagoner, Infante \& Brown, Genetic Effects Associated with Industrial Chemicals, in SOEH CONFERENCE, supra note 24, at 100; Waxweiler, Stringer, Wagoner, Jones, Falk \& Carter, Neoplastic Risk among Workers Exposed to Vinyl Chloride, 271 AnNals N.Y. Acad. SCI. 40 (1976).

OSHA promulgated standards regulating workplace exposure to vinyl chloride, see 29 C.F.R. $\$ 1910.1017$ (1980), after the first reported deaths of vinyl chloride workers in 1972. See Society of the Plastics Indus., Inc. v. OSHA, 509 F.2d 1301, 1305 (2d Cir.), cert. denied, 421 U.S. 992 (1975). The court upheld the validity of the standards in the face of industry attack. Id. 1310-11.

A recent study indicates that "reduction in exposure to vinyl chloride is accompanied by a reduction in the chromosomal abnormalities to levels indistinguishable from those of controls." Anderson, Richardson, Weight, Purchase \& Adams, Chromosomal Analyses in Vinyl Chloride Exposed Workers, 79 Mutation RESEARCH 151, 151 (1980).

31 See Doerr v. B.F. Goodrich Co., 484 F. Supp. 320, 326 n.4 (N.D. Ohio 1979) (discussing briefly the state of medical evidence concerning the relative risks of birth defects induced by exposure to vinyl chloride among male and female workers). See generally Ducatman, Hirschhorn \& Selikoff, Vinyl Chloride Exposure and Human Chromosome Aberrations, 31 MUtation Research 163 (1975); Infante, McMichael, Wagoner, Waxweiler \& Falk, Genetic Risks of Vinyl Chloride, 1 LANCET 734 (1976); Manson, supra note 16, at 322; Wagoner, Infante \& Brown, supra note 30 , at $101-02$.

32 Infante, McMichael, Wagoner, Waxweiler \& Falk, supra note 31, at 734-35; Wagoner, Infante \& Brown, supra note 30 , at 101.

33 Infante, McMichael, Wagoner, Waxweiler \& Falk, supra note 31, at 735; Infante, Wagoner \& Waxweiler, Carcinogenic, Mutagenic and Teratogenic Risks Associated with Vinyl Chloride, 41 Mutation Research 131, 140 (1976).

34 Infante, Oncogenic and Mutagenic Risks in Communities with Polyvinyl Chloride Production Facilities, 271 AnNals N.Y. ACAD. ScI. 49, 56 (1976); Wagoner, Infante \& Brown, supra note 30, at 101.

35 Infante, Mutagenic and Carcinogenic Risks Associated with Halogenated Olefins, 21 Envt'l Healtr Perspectives 251, 251 (1977); Wagoner, Infante \& Brown, supra note 30 , at 102 . 
riages. ${ }^{36}$ Evidence of abnormal rates of chromosomal aberrations in male workers indicates that chloroprene may be mutagenic in males. ${ }^{37}$

\section{G. Other Industrial Agents}

Many other substances widely used in industry are known or suspected to have adverse effects on the reproductive systems of occupationally exposed workers. Chromosomal change has been reported in workers exposed to the solvent benzene, an element of paint strippers, rubber cement, nylon, and detergents. ${ }^{38}$ Anesthetic gases and ionizing radiation produce miscarriages and birth defects in offspring of male and female operating room, $x$-ray, and dental personnel. ${ }^{39}$ Occupational exposure to pesticides and chlorinated hydrocarbons, used to manufacture drycleaning fluid and other general solvents, causes serious fetal damage. ${ }^{40}$ The widespread use of organic and inorganic mercury compounds in thermometers, dental fillings, neon lights, mirrors, drugs, dyes, and explosives, among other common consumer goods, makes especially disturbingthe findings of cerebral palsy and severe mental retardation in children of exposed mothers. ${ }^{41}$

\section{In Summary}

The few extensive studies that have been done suggest that the toxins studied cause reproductive harm to both the male and female worker, which may then manifest itself as a birth defect in the

36 Wagoner, Infante \& Brown, supra note 30 , at 102.

37 Id.

38 A. Hrucko \& M. Brunt, supra note 23, at C-19, C-20; Picciano, Cytogenetic Study of Workers Exposed to Benzene, 19 ENVT'L Research 33, 34 (1979).

${ }^{39}$ Ad Hoc Committee on the Effect of Trace Anesthetics on the Health of Operating Room Personnel, American Society of Anesthesiologists, Occupational Disease Among Operating Room Personnel: A National Study, 41 ANESTHESIoLocy 321 (1974); Corbett, Cornell, Endres \& Lieding, Birth Defects Among Children of Nurse-anesthetists, 41 ANESTHESIOLOGX 341 (1974); Hunt, Occupational Radiation Exposure of Women Workers, 7 Preventrve MED. 294 (1978); Infante, Genetic Hazards of Anesthetic Gases: An Epidemiologic Study, 13 CunNICAL GENETICS 123 (1978).

40 See A. Hrucko \& M. Brunt, supra note 23, at C-19, C-30 to C-33; Whorton, Krauss, Marshall \& Milby, Infertility in Male Pesticide Workers, 2 LANCET 1259 (1977) (male infertility appeared to be related to duration of exposure to pesticide).

41 Harada, Congenital Minamata Disease: Intrauterine Methylmercury Poisoning, 18 Teratologx 285 (1978); Smith, Congenital Minamata Disease: MethylMercury Poisoning and Birth Defects in Japan, SOEH CONFERENCE, supra note 24, at 75; Wilson, Environmental Chemicals, in 1 HANDBOOK OF TERATOLOGY 357, 368 (J. Wilson \& E. Fraser eds. 1977). 
worker's offspring. Such toxins often act prior to conception, and therefore efforts undertaken by the employer to protect pregnant employees only do not completely address the problem. Aside from these studies, most research accumulated on the subject of reproductive harm has focused on the pregnant worker, without due regard for the possibility of reproductive harm to males and nonpregnant females. ${ }^{42}$ Use of these single-sex studies to justify a policy that excludes only women threatens to distort the factual record. Thus, discrimination might be judged permissible when it would not be were a fuller factual record available.

Of course, there may come a time when the workplace has been made healthful vis-à-vis the reproductive system of the workerthat is, the mutagenic and gametotoxic effects of a particular hazard have been eliminated-but has not yet been made safe for the embryo or fetus because teratogenic effects remain. Even in this case, however, the bright line of pregnancy is not a sufficient guide in establishing the class of workers warranting protection. Many teratogens pose their greatest risk to the developing embryo during the first trimester of pregnancy ${ }^{43}$ when the mother is not likely to know that she is pregnant. It will thus be difficult to design a policy that responds adequately to both women's employment rights and the danger of harm to the unborn.

\section{The Occupational Safety and Health Act OF 1970}

Although the focus of this Article is an analysis under title VII of employer policies that exclude fertile women, a digression is merited to discuss the possible applicability of the Occupational Safety and Health Act of $1970^{44}$ (OSH Act) to this problem. The part of the OSH Act relevant here requires the employer to maintain a safe and healthful workplace for his employees. The statutory embodiment of this requirement takes two forms-compliance with standards promulgated by the Occupational Safety and Health Administration (OSHA) and enforcement proceedings for violation of the OSH Act "general duty" clause.

42 See Manson, supra note 16, at 329-30.

43 See Furnish, supra note 15, at 122 n.259; Wilson, Current Status of Teratology, in 1 HandBook of Teratology 47, 50-54 ( $\mathrm{J}$. Wilson \& E. Fraser eds. 1977); Mrch. Note, supra note 15, at 240 . Lead, for instance, poses the greatest risk in the first trimester. See Bridbord, supra note 22, at 318 .

4429 U.S.C. $\$ \$ 651-678$ (1976, Supp. II 1978 \& Supp. III 1979). See generally M. Rothsten, Occupational. SAFETY AND HEalth Law (1978 \& Supp. 1980); J. Stadi, C. Thompson \& F. Bern, Agency, Partnerseit and Emiployment (1980). 
Under its standard setting power, ${ }^{45}$ OSHA has broad authority to mandate "practices, means, methods, operations, or processes, reasonably necessary or appropriate to provide safe or healthful em. ployment and places of employment." 46 Any standard promulgated must be one that "most adequately assures, to the extent feasible" 47 that no employee will suffer a material impairment to his or her health during the course of his or her working life. OSHA is also empowered to promulgate "temporary emergency standards" when the threat to employee health is sufficiently severe. ${ }^{48}$

45 See 29 U.S.C. $\$ 654$ (a) (2) (1976).

$46 \mathrm{Id}$. $\$ 652(8)$. Such "practices, means, [and] methods" include not only elimination of the hazard from the employee's working environment but also such protective measures as warnings, protective equipment, and regularly scheduled medical examinations when elimination of the hazard is not a feasible alternative. See id. $\$ 655(\mathrm{~b})(7)$.

47 The concept of feasibility has both a technological and economic component. See generally Berger \& Riskin, Economic and Technological Feasibility in Regulating Toxic Substances Under the Occupational Safety and Health Act, 7 Ecolocy L.Q. 285 (1978). The courts have generally interpreted the OSH Act to be "technology forcing," and, as such, OSHA may promulgate standards that, within limits, require the improvement of existing or the development of new technologies. See American Iron \& Steel Inst. v. OSHA, 577 F.2d 825, 838 (3d Cir. 1978), cert. granted, $100 \mathrm{~S}$. Ct. 3054 (1980); Society of Plastics Indus., Inc. v. OSHA, 509 F.2d 1301, 1309 (2d Cir.), cert. denied, 421 U.S. 992 (1975); Berger \& Riskin, supra, at 318-21. Considerations of cost to the employer are also relevant to the determination of feasibility, see Industrial Union Dep't v. Brennan, 530 F.2d 109, 122-23 (3d Cir. 1975), although merely because a standard is financially burdensome does not mean that compliance thereto is infeasible. See Industrial Union Dep't v. Hodgson, 499 F.2d 467, 478 (D.C. Cir. 1974). To be economically infeasible, the standard must threaten the financial integrity of the industry as a whole; the demise of some marginal employers is not enough. Id.

In recent years the concept of feasibility has taken on an increasingly economic hue. The Fifth Circuit now requires OSHA to justify any proposed standard by reference to a full-blown cost-benefit analysis, see American Petroleum Inst. v. OSHA, 581 F.2d 493 (5th Cir. 1978), affd on other grounds sub nom. Industrial Union Dep't v. American Petroleum Inst., $100 \mathrm{~S}$. Ct. 2844 (1980), a position supported in part by at least one Supreme Court Justice. See Industrial Union Dep't v. American Petroleum Inst., 100 S. Ct. 2844, 2875-78 (1980) (Powell, J., concurring). See also American Textile Mfrs. Inst. v. Marshall, 617 F.2d 636 (D.C. Cir. 1979), cert. granted, 101 S. Ct. 68 (1980) (reviev of the OSHA cotton-dust standard; the Supreme Court has agreed to decide whether or not the OSH Act requires OSHA to cost-justify its standards). By executive order, ex-president Jimmy Carter required all agencies, including OSHA, to draft an "economic impact statement" for all regulations for which a major economic effect is anticipated. See Exec. Order No. 12,044, 3 C.F.R. 152 (1979), reprinted in 5 U.S.C. $\$ 553$ (Supp. III 1979). The Occupational Safety and Health Review Commission (OSHRC), the quasi-judicial independent agency with jurisdiction to review OSHA citations, see text accompanying note 55 infra, has begun to engage in cost-benefit analyses. See, e.g., Secretary of Labor v. American Cyanamid Co., OSHRC Docket No. 79-2438, at 21-22 (August 20, 1980).

48 See 29 U.S.C. $\$ 655(c)$ (1976); M. Rothsten, supra note 44 , at $\$ 31$. Congress also granted OSHA the authority to adopt the broad range of public and private industrial safety and health standards that predated the OSH Act. See 29 U.S.C. $\$ \$ 653(b)(2), 655(a)$ (1976). Most of these so-called "interim standards" concerned employee safety as opposed to employee health, and thus have little bearing on a discussion of toxins in the workplace. See Berger \& Riskin, supra note 47 , at 295. 
Under the Act's "general duty" clause, the employer is charged with maintaining a workplace "free from recognized hazards that are causing or likely to cause death or serious physical harm" to employees. 49 A "recognized hazard" is a dangerous condition known either by the particular employer or generally within the given industry to be hazardous. ${ }^{50}$ Unpreventable hazards are deemed not to be recognized. 51

Enforcement under the OSH Act is primarily by way of citation ${ }^{52}$ and fine ${ }^{53}$ coming at the heels of an OSHA-conducted inspection. ${ }^{54}$ The employer may contest a citation or fine before the Occupational Safety and Health Review Commission (OSHRC), a quasi-judicial administrative body operating independently of OSHA. ${ }^{55}$ The findings of the Commission may be appealed to the federal appellate courts. ${ }^{56}$

Although the OSH Act, unlike title VII, specifically addresses the problem of workplace hazards, it alone is not adequate to remedy sex-based employment discrimination purportedly justified by the risk of reproductive harm. The OSH Act does not, for instance, contain any sex-sensitive antidiscrimination provision; nothing in the Act expressly prevents an employer from excluding an entire class if he so chooses. ${ }^{57}$ The OSH Act would come into play only if the employer opted to employ members of a given sex and the workplace was unhealthful for them. But even here, the Act's protection is not necessarily complete, as the employer may be

4929 U.S.C. $\$ 654$ (a) ( I) (1976).

50 See Usery v. Marquette Cement Mfg. Co., 568 F.2d 962 (2d Cir. 1977); Brennan v. OSHRC, 501 F.2d 1196 (7th Cir. 1974). 1973).

51 See National Realty \& Const. Co. v. OSHA, 489 F.2d 1257 (D.C. Cir.

5229 U.S.C. $\$ \$ 658,659$ (1976); see M. RothsteIn, supra note 44, at $\$ \$ 241-252$.

5329 U.S.C. $\$ 666$ ( 1976 ).

54 Id. $\$ 570$; see M. Rothstenv, supra note 44, at $\$ \$ 221-233$.

55 See 29 U.S.C. $\$ 661$ (1976, Supp. II 1978 \& Supp. III 1979); Berger \& Riskin, supra note 47, at 303-09.

5629 U.S.C. $\$ 660$ (1976).

57 See Secretary of Labor v. American Cyanamid Co., OSHRC Docket No. 79-5762 (July 15, 1980), in which OSHA charged that American Cyanamid's "fetus protection policy," which conditioned employment for fertile women in the lead pigments division on sterilization, violated OSHA's general duty clause. The administrative law judge rejected this contention because, inter alia, issues involving sex discrimination are preempted from OSHA's jurisdiction by title VII. See id. 9-11; 29 U.S.C. $\$ 653(\mathrm{~b})(1)$ (1976); note 11 supra; notes $241-54$ infra \& accompanying text. On the subject of preemption of the OSH Act by other federal statutes, see generally Comment, Interpreting OSHA's Pre-emption Clause: Farmworkers as a Case Study, 128 U. PA. L. Rev. 1509 (1980). 
under no legal obligation to eliminate the reproductive hazard. If, for example, the hazard is not "recognized," no duty to eliminate it attaches under the general duty clause. And even if the hazard is recognized, it is an open question whether a hazard impinging only upon the reproductive system is one likely to cause "death or serious physical harm" to employees. This would leave whatever relevant standards OSHA had promulgated as the only source of any employer duty to eliminate the hazard.

Even protection under OSHA-promulgated standards may be inadequate. First, there may be no applicable standard. Given the propensity of industry to litigate virtually every permanent standard issued ${ }^{58}$ and the slowness with which OSHA promulgates permanent standards in the first place, ${ }^{59}$ there remain large numbers of toxins about which OSHA has done nothing.

Second, an existing standard may not afford adequate protection against reproductive harm. Both the appellate courts and the administrative agencies have begun to subject regulations to socalled "cost-benefit" analysis, and zero-risk standards are unlikely to be mandated. ${ }^{00}$ This will probably have its greatest impact in situations of teratogenic harm only. In those cases, the employee, often less susceptible than the fetus, would not be harmed, and causation may be difficult to prove. ${ }^{61}$ Even if the causal link is clear, the harm to the unborn might more cheaply be avoided by such measures as wholesale exclusion or a policy requiring birth control or sterilization as a condition of employment. ${ }^{62}$ If a line

58 See, e.g., American Textile Mfrs. Inst. v. Marshall, 617 F.2d 636 (D.C. Cir. 1979) (cotton dust), cert. granted, 101 S. Ct. 68 (1980); American Petroleum Inst. v. OSHA, 581 F.2d 493, 500 (5th Cir. 1978) (benzene), aff'd sub nom. Industrial Union Dep't v. American Petroleum Inst., $100 \mathrm{~S}$. Ct. 2844 (1980); American Iron \& Steel Inst. v. OSHA, 577 F.2d 825 (3d Cir. 1978) (coke oven emissions), cert. granted, $100 \mathrm{~S}$. Ct. 3054 (1980); Society of Plastics Indus., Inc. v. OSHA, 509 F.2d 1301 (2d Cir.) (vinyl chloride), cert. denied, 421 U.S. 992 (1975); Industrial Union Dep't v. Hodgson, 499 F.2d 467 (D.C. Cir. 1974) (asbestos dust).

59 See Furnish, supra note 15, at 68 \& n.22.

60 See note 47 supra; Furnish, supra note 15, at 69-70.

61 A plurality of the Supreme Court, in invalidating OSHA's permanent standards for exposure to benzene, a suspected carcinogen, required that OSHA prove by substantial evidence that the hazard in question poses a "significant risk" to the health of employees, and that compliance with the proposed standards will materially reduce that risk. See Industrial Union Dep't v. American Petroleum Inst., 100 S. Ct. 2844, 2865 (1980). Given the dearth of credible scientific evidence linking many suspect chemicals with reproductive harm, see note 16 supra \& accompanying text, this burden of proof may be especially difficult for OSHA to meet in the context of standard promulgation for protection against reproductive harm.

62 This is not to say that either of these alternatives actually would be allowed under the OSH Act. 
must be drawn, it will probably be drawn at a point that leaves some harm to the unborn as a substantial risk.

Finally, the OSH Act enforcement mechanism is ill-suited to remedy problems related to reproductive harm and sex discrimination. The broad, affirmative relief available under title VII cannot be had under the OSH Act, as the citation and fine system permits only an ineffective form of monetary coercion. ${ }^{63}$ Injunctive relief is available only upon petition of the Secretary of Labor, and only when the danger alleged could "reasonably be expected to cause death or serious physical harm" ${ }^{44}$-a standard unlikely to be met in the case of reproductive injury. Employees themselves have virtually no direct power to instigate a proceeding. ${ }^{65}$ They may lodge a complaint with the Occupational Safety and Health Administration, but OSHA decides whether an inspection is warranted.68

From the employee's perspective, therefore, the OSH Act provides limited access for redress and no individual remedy for violations. Title VII, which provides broad, equitable remedies and a private right of action, is a more effective statutory tool.

\section{TITLE VII}

Title VII ${ }^{67}$ is the primary federal antidiscrimination statute. Under title VII, the employer will not be permitted to claim that he or she has no duty to eliminate the reproductive hazard merely because discrimination is much "cheaper" than cleaning up the workplace. Such unwarranted discrimination is exactly what title VII forbids. Nor will the employer be permitted to justify discrimination by pointing to the possibility of reproductive harm. Instead, title VII may actually place upon the employer a duty to clean up the workplace independent of, but analogous to, that imposed by the OSH Act. At the least, the employee would be entitled to reinstatement and back pay as the result of a favorable order. The employee is thus likely to turn to title VII to obtain complete relief.

${ }^{63}$ See notes $52-54$ supra \& accompanying text.

6429 U.S.C. $\$ 662$ (a) (1976). As of the date of this Article's publication, there are no reported cases in which injunctive relief has been sought or granted under this section.

65 The only exception is if OSHA "arbitrarily or capriciously" fails to seek injunctive relief, in which case an employee in "imminent danger" may petition in federal district court for a writ of mandamus against the Secretary of Labor. 29. U.S.C. $\$ 662(d)(1976)$.

66 See 29 U.S.C. $\$ 657(f)(1)(1976)$.

6742 U.S. $\$ \$ 2000$ e to 2000 e-17 (1976 \& Supp. III 1979). 


\section{A. The Analytical Framework}

Section 703(a)(1) of title VII prohibits employers "to fail or refuse to hire or to discharge any individual, or otherwise to discriminate against any individual with respect to his compensation, terms, conditions, or privileges of employment, because of such individual's ... sex." 68

A plaintiff seeking title VII relief has the initial burden of establishing a prima facie case of discrimination. ${ }^{\text {Bg }}$ To establish the prima facie case, a plaintiff can proceed under a disparate treatment or a disparate impact theory. ${ }^{70}$ Under a disparate treatment theory, the plaintiff alleges that the employer "simply treats some people less favorably than others because of their race, color, religion, sex, or national origin." 71 Proof of a discriminatory motive is crucial in disparate treatment cases, but direct proof of actual intent to discriminate is not required. ${ }^{72}$

When the plaintiff produces evidence sufficient to establish a prima facie case of disparate treatment, the burden shifts to the employer to articulate a legitimate, nondiscriminatory reason for the action in question. ${ }^{73}$ The Supreme Court has emphasized that this burden is not a heavy one. ${ }^{74}$ Once the employer articulates a legitimate explanation for his action, the plaintiff may rebut the stated reason as pretextual. ${ }^{76}$

6842 U.S.C. $\$ 2000 \mathrm{e}-2(a)$ (1) (1976).

69 Albemarle Paper Co. v. Moody, 422 U.S. 405, 425 (1975); L. ModjESEA, Handling Employment Discrimanation Cases $\$ 1.8$ (1980). (1977).

70 International Bhd. of Teamsters v. United States, 431 U.S. 324, 335 n.15

71 Id; see McDonnell Douglas Corp. v. Green, 411 U.S. 792 (1973).

72 For example, intent can be inferred from convincing statistical evidence. See International Bhd. of Teamsters v. United States, 431 U.S. 324, 335 n.15 (1977).

73 Furnco Constr. Corp. v. Waters, 438 U.S. 567, 581-82 (1978) (Marshall, J., concurring and dissenting); McDonnell Douglas Corp. v. Green, 411 U.S. 792, 802-03 (1973).

74 The defendant need not persuade the court that it was actually motivated by the proffered reasons. ... It is sufficient if the defendant's evidence raises a genuine issue of fact as to whether it discriminated against the plaintiff. To accomplish this, the defendant must clearly set forth, through the introduction of admissible evidence, the reasons for the plaintiff's rejection.

Texas Dep't of Community Affairs v. Burdine, 49 U.S.L.W. 4214, 4216 (U.S. Mar. 3, 1981) (No. 79-1764) (citation and footnotes omitted) (emphasis added). See Board of Trustees of Keene State College v. Sweeney, 439 U.S. 24, 25 (1978) (per curiam). Courts have emphasized that the burden of articulating a reason does not affect the burden of persuasion, which at all times rests with the plaintiff. Kunda v. Muhlenberg College, 621 F.2d 532, 543 n.3 (3d Cir. 1980); Loeb v. Textron, Inc., 600 F.2d 1003, 1014-15 (1st Cir. 1979).

${ }^{75}$ McDonnell Douglas Corp. v. Green, 411 U.S. 792, 802-03 (1973). "The method suggested in McDonnell Douglas for pursuing this inquiry, however, was 
Employers facing a disparate treatment claim may in a few cases avail themselves of a statutory exception. Title VII does permit discriminatory action based upon sex when sex is a bona fide occupational qualification (BFOQ) reasonably necessary to the normal operation of the particular enterprise. ${ }^{76}$ The BFOQ defense has been construed as an extremely narrow exception to the prohibition against sex discrimination. ${ }^{77}$ The defense will not validate employment practices based upon stereotypes, generalizations, or state protective laws that embody such generalizations. ${ }^{78}$

Under a disparate impact theory, the plaintiff claims that a facially neutral employment practice violates title VII because its effects fall more harshly on one protected group than another. ${ }^{79}$ Proof of discriminatory motive is irrelevant. ${ }^{80}$ If the plaintiff can establish that a neutral employment practice has a disparate impact, the employer must show that the challenged practice has a "manifest relationship to the employment in question." 81 Not only must the practice be "job-related," 82 but there must be no less discriminatory alternative available to the employer to accom-

never intended to be rigid, mechanized, or ritualistic. Rather, it is merely a sensible, orderly way to evaluate the evidence in light of common experience as it bears on the critical question of discrimination." Furnco Constr. Corp. v. Waters, 438 U.S. 567,577 (1978).

7642 U.S.C. $\$ 2000$ e-2(e)(1) (1976). See L. ModJESKA, supra note 69 , at \$1.18; James \& Alaimo, BFOQ: An Exception Becoming the Rule, 26 CLEv. ST. L. Rev. 1 (1977); Sirota, Sex Discrimination: Title VII and the Bona Fide Occupational Qualification, 55 TEx. L. REv. 1025 (1977).

77 Dothard v. Rawlinson, 433 U.S. 321, 334 (1977).

78 See Phillips v. Martin Marietta Corp., 400 U.S. 542 (1971) (per curiam); Rosenfeld v. Southern Pac. Co., 519 F.2d 527 (9th Cir. 1975); L. ModJEska, supra note 69 , at $\$ 1.18$.

79 Griggs v. Duke Power Co., 401 U.S. 424 (1971). See L. MODJESKA, supra note 69 , at $\$ 1.9$.

80 Dothard v. Rawlinson, 433 U.S. 321, 329 (1977); International Bhd. of Teamsters v. United States, 431 U.S. 324, 335 n.15 (1977); Griggs v. Duke Power Co., 401 U.S. 424,432 (1971). Plaintiffs may rely on statistical evidence to establish the disparate impact of the challenged practice. See International Bhd. of Teamsters, 431 U.S. at 339-40. Such statistics, however, are not irrefutable and "their usefulness depends on all of the surrounding facts and circumstances." Id. 340; accord, New York City Transit Auth. v. Beazer, 440 U.S. 568, 584-87 (1979); Hazelwood Sch. Dist. v. United States, 433 U.S. 299, 307-08 (1977). See also L. ModJESKa, supra note 69 , at $\$ 1.10$.

81 Griggs v. Duke Power Co., 401 U.S. 424, 432 (1971). But see New York City Transit Auth. v. Beazer, 440 U.S. 568, 587 n.31 (1979), suggesting that, as in disparate treatment cases employing the McDonnell Douglas test, see notes 73-75 supra \& accompanying text, the ultimate burden of persuasion resides with the plaintiff.

82 Dothard v. Rawlinson, 433 U.S. 321, 332 (1977).

Some courts of appeals permit the employer to assert other "legitimate" business interests besides job-relatedness as a justification for impact discrimination. See, e.g., Robinson v. Lorillard Corp., 444 F.2d 791, 797-800 (4th Cir.), cert. dismissed, 404 U.S. 1006 (1971). 
plish the same end. ${ }^{83}$ Of course, if the plaintiff can prove that the facially neutral policy is a pretext for purposeful discrimination, no such defense is available to the employer. The case simply becomes one of disparate treatment, justifiable only if the employer can prove that sex is a BFOQ.84

\section{B. Analysis Under Current Title VII Law}

The first question to be answered is whether title VII ${ }^{85}$ in its current form would ever countenance the practice of excluding fertile women, but not fertile men, ${ }^{86}$ from employment on the basis of the possible harm to their unborn. The short answer is no. Current law would hold such a policy to be sex discrimination not justifiable under any existing formulation of either the bona fide occupational qualification (BFOQ) defense or the manifest business necessity defense.

\section{Does the Exclusion Constitute Sex Discrimination?}

As the discussion below demonstrates, any employer policy that results in the exclusion of fertile women, but not fertile men, from the workplace would be considered sex discrimination under title VII. This conclusion can be reached in any of four alternative ways.

First, I will argue that the 1978 "pregnancy amendment" to title VII, ${ }^{87}$ which prohibits discrimination in employment on the basis of pregnancy, childbirth, and related medical conditions, also prohibits discrimination on the basis of the capacity to become pregnant. Second, even if the pregnancy amendment were found to be inapplicable, the refusal to hire fertile women imposes upon women a requirement for employment that is not imposed on menthe inability to reproduce. This constitutes an unlawful sex classification under section $703(a)(1)$ of title VII. A similar analysis

83 Dothard v. Rawlinson, 433 U.S. 321, 332 (1977). The burden of proving the existence of a less discriminatory alternative resides with the plaintiff. But see New York City Transit Auth. v. Beazer, 440 U.S. 568, 587 n.31 (1979), in which the Court made no mention of the less-discriminatory-alternative leg of the Dothard test despite an employer policy that was massively over-inclusive.

84 See text accompanying notes 76-78 supra.

8542 U.S.C. $\$ \S 2000$ e to 2000 e-17 (1976 \& Supp. III 1979).

86 The word "fertile" is used throughout this Article to mean "capable of reproducing," and refers to both men and women.

8742 U.S.C. $\$ 2000 \mathrm{e}$ (k) (Supp. III 1979). 
applies in those cases in which the substance harms both male and female workers (or their offspring) but the employer protects only female workers from the health risks of occupational exposure. Finally, the exclusion of fertile women from employment has a clearly disproportionate adverse impact upon the employment opportunities of women.

\section{a. The 1978 "Pregnancy Amendment"}

In October 1978, Congress amended title VII by adding section $701(\mathrm{k})$, which prohibits discrimination in employment "because of or on the basis of pregnancy, childbirth, or related medical conditions." 88 The specific purpose of Congress in enacting section 701(k) was to overturn the result in General Electric Co. v. Gil$b_{e r t}{ }^{89}$ in which the Supreme Court held that the employer, whose disability income insurance plan excluded pregnancy from coverage, did not violate title VII.90 The Court found that the plan discriminated not against the class of women workers but only against the class of pregnant workers.91 In so holding, the Court missed the obvious fact that pregnancy is a unique female characteristicand that any classification based on pregnancy is, inevitably, a sexbased classification. Instead, the Court held that pregnancy is an objectively identifiable condition, and that a classification based

88 Pub. L. No. 95-555, $\$ 1,92$ Stat. 2076 (codified at 42 U.S.C. $\$ 2000 \mathrm{e}(\mathrm{k})$ (Supp. III 1979)).

89429 U.S. 125 (1976).

${ }^{90}$ The congressional intent to overrule Gilbert is evident on the face of the statutory text, quoted here in relevant part:

The terms "because of sex" or "on the basis of sex" include, but are not limited to, because of or on the basis of pregnancy, childbirth, or related medical conditions; and women affected by pregnancy, childbirth, or related medical conditions shall be treated the same for all employment-related purposes, inchuding receipt of benefits under fringe benefit programs, as other persons not so affected but similar in their ability or inability to work, and nothing in section $2000 \mathrm{e}-2(\mathrm{~h})$ of this title shall be interpreted to permit otherwise.

42 U.S.C. $\$ 2000 \mathrm{e}(\mathrm{k})$ (Supp. III 1979) (emphasis added).

For the one case construing this amendment since its enactment, see Harriss v. Pan Am. World Airways, Inc., 24 Empl. Prac. Dec. $\llbracket 31,425$ (9th Cir. 1980). Some courts have simply not gotten the message. See Burwell v. Eastern Air Lines, Inc., 633 F.2d 361, 370 (4th Cir. 1980) (assuming that discrimination on the basis of pregnancy is not disparate treatment without ever mentioning the amendment), cert. denied, 49 U.S.L.W. 3643 (U.S. Mar. 3, 1981) (Nos. 80-868 \& 80-1076).

The passage of the pregnancy amendment does not completely bury Gilbert. The amendment is not retroactive, see Condit v. United Air Lines, Inc., 631 F.2d 1136, 1139-40 (4th Cir. 1980), and hence discrimination on the basis of capacity to conceive occurring before the amendment's passage must be analyzed as if Gilbert were still good law.

For a detailed analysis of the legislative history of the amendment, see Furnish, supra note 15, at 77-83.

91429 U.S. at 134-35 (relying on Geduldig v. Aiello, 417 U.S. 484 (1974)). 
thereon is not a sex classification, but rather a classification based on a characteristic possessed by some women.92

Section 701(k) clearly "corrects" the Gilbert result." But the intended scope of the amendment is not apparent on the face of the statutory text. The section does not, for example, speak explicitly to discrimination on the basis of the woman's fertility, or capacity to become pregnant. It is difficult to avoid the conclusion, however, that the pregnancy amendment was intended to encompass just such capacity. The House report accompanying section 701(k) states that the purpose of the bill was to extend protection against all forms of sex discrimination "to the whole range of matters concerning the childbearing process." 94 The report states that "the assumption that women will become pregannt [sic] and leave the labor force leads to the view of women as marginal employees, and is at the root of the discriminatory practices which keep women in low-paying and dead-end jobs." 95 The report further quotes with approval the observation of Justice Stevens, dissenting in Gilbert, that "it is the capacity to become pregnant which primarily differentiates the female from the male." 96

Section $701(k)$ thus was intended not only to forbid discrimination against pregnant workers, but also to forbid discrimination against workers with the capacity to become pregnant. The amendment reaffirms the principle that all workers, including pregnant and potentially pregnant workers, "be treated the same as other employees on the basis of their ability or inability to work." ${ }^{9 \tau}$

\section{b. Reproductive Capacity as a Sex-Based Condition for Employment}

A court may, of course, find that the "pregnancy amendment" applies only to employees who are or have been pregnant and does not protect employees who have been discriminated against because of their capacity to become pregnant. Such a finding would not end the inquiry as to whether discrimination in hiring based on childbearing capacity constitutes sex discrimination actionable under section $703(a)(1)$ of title VII. Even without the benefit of

$82 \mathrm{Id}$.

93 See note 90 supra.

94 H.R. ReP. No. 948, 95th Cong., 2d Sess. 5, reprinted in [1978] U.S. CoDz Cong. \& AD. NEws $4749,4753$.

95 Id. 3, reprinted in [1978] U.S. CoDE CoNG. \& AD. NEws at 4751.

96 Id. 2, reprinted in [1978] U.S. CoDE CoNG. \& AD. NEws at 4750 (quoting General Elec. Co. v. Gilbert, 429 U.S. 125, 162 (1976) (Stevens, J., dissenting)) (emphasis added).

97 Id. 3, reprinted in [1978] U.S. Code Cong. \& AD. NEws at 4751. 
the pregnancy amendment, it can be forcefully argued that the employer who excludes fertile women discriminates among reproductively capable employees solely on the basis of sex.

The employer who excludes women with childbearing capacity from certain jobs imposes upon all women, and upon no men, the employment condition that they be incapable of reproducing. In effect, he chooses among all reproductively capable applicants only the males and rejects the females. He further discriminates among the potential employees by requiring females to disclose personal information that is not asked of the males. This constitutes disparate treatment on the basis of sex.

The employer, citing Gilbert, may argue that the capacity to bear children is an objectively identifiable, ${ }^{98}$ gender-neutral condition and that the classification based thereon happens to exclude only women. On the surface, this argument is appealing. "Capacity to become pregnant," says the employer, "is analogous to being pregnant"-and even if such capacity falls outside the parameters of the pregnancy amendment, it clearly is within the bounds of the Gilbert decision. Thus, following Gilbert's logic, an employer who discriminates against persons with the capacity to become pregnant is not discriminating on the basis of sex-even though every person in the discriminated-against class happens to be a woman.

This reasoning is facile, but fallacious. Such a "sex-plus" argument has already been rejected by the Supreme Court in the context of discrimination against mothers with children, ${ }^{99}$ and presumably would be rejected here. ${ }^{100}$ Gilbert does not compel any

98 The capacity to bear children is not actually an objectively identifiable condition. Absent a physical defect of some kind or a sterilization procedure, all women of childbearing age are assumed to be capable of conceiving.

99 See Phillips v. Martin Marietta Corp., 400 U.S. 542 (1971) (per curiam). The employer in Phillips refused to hire mothers, but not fathers, of small children. See Phillips v. Martin Marietta Corp., 411 F.2d I (5th Cir.), petition for rehearing en banc denied, 416 F.2d 1257 (5th Cir. 1969), vacated and remanded per curiam, 400 U.S. 542 (1971). The Supreme Court remanded for fuller development of the record, noting, however, that section 703(a) did not permit "one hiring policy for women and another for men-each having pre-school-age children." 400 U.S. at 544.

100 Cf., e.g., Harper v. Thiokol Chem. Corp., 619 F.2d 489, 492 (5th Cir. 1980) (employer required female employee on maternity leave to experience a normal menstrual cycle before permitting her to return to work); In te Consolidated Pretrial Proceedings in the Airline Cases, 582 F.2d 1142, 1145 (7th Cir. 1978) (motherhood), cert. granted sub nom. Zipes v. Trans World Airlines, Inc., 49 U.S.L.W. 3663 (U.S. Mar. 10, 1981) (No. 78-1545); Jacobs v. Martin Sweets Co., 550 F.2d 364, 369-71 (6th Cir. 1977) (unwed pregnancy).

The courts have been somewhat more accepting of the "sex-plus" argument in the context of discrimination based upon both sex and personal appearance. See 
other result. The Gilbert Court, after all, distinguished between pregnant and nonpregnant persons. The analogous distinction here is between fertile and nonfertile persons. For while the capacity to bear children is admittedly a unique female characteristic, it is nonetheless merely the feminine role in the general human capacity to reproduce. Thus, even under the Gilbert rationale, any employment policy that discriminated against fertile women only (as opposed to fertile persons, both men and women) clearly discriminates on the basis of sex.

\section{c. Relative Risk of Harm as a Sex-Based Classification}

The employer may articulate a legitimate interest in avoiding the risk of harm to the female worker or her future child as the basis for the classification. The employer will assert that a classification based on this risk factor does not constitute disparate treatment.

This argument is untenable. In the case of lead, for example, occupational exposure has multiple adverse effects on the reproductive systems of both male and female workers. ${ }^{101}$ The medical experts have not, however, established a direct causal relationship between the mutagenic and teratogenic effects of lead and particular congenital birth defects. ${ }^{102}$ The employer cannot, therefore, establish that there are identifiable preconception injuries to which potential children of exposed woman are vulnerable and from which children of exposed men are immune. There is, as well, no medical evidence that establishes the relative risks of harm to exposed males and females. Thus, while the practice of excluding fertile women discriminates literally on the basis of the capacity to bear children, the employer discriminates on the basis of sex by protecting its female employees, but not its male employees, from the risk of producing a congenitally defective child. The discrimination occurs within the class of reproductively capable workers who face a risk of injury to themselves or a future child from occupational exposure to lead, and the line is drawn according to the sex of the potential parent.

Willingham v. Macon Tel. Publishing Co., 507 F.2d 1084, 1089-92 (5th Cir. 1975) (en banc) (employer may refuse to employ long-haired males while hiring long-haired females; Phillips distinguished on the ground that the latter involved the "fundamental right" to bear children). But see Carroll v. Talman Fed. Sav. \& Loan Ass'n, 604 F.2d 1028 (7th Cir. 1979) (employer may not require only female bank personnel to wear uniforms).

101 See notes 21-26 supra \& accompanying text.

102 J. STELIMAN, supra note 16, at 151-52. 
Even if the employer could show that women as a class face a greater average risk of injury from occupational exposure to a toxic substance than do men, ${ }^{103}$ the practice of excluding fertile women nonetheless constitutes disparate treatment under section 703(a)(1). As the Supreme Court made clear in City of Los Angeles Department of Water and Power v. Manhart, ${ }^{104}$ statistically verifiable generalizations about the sexes will not rebut a claim of disparate treatment under that section. There, the Court held that an employer who charged women employees a greater monthly contribution than was charged men for the same pension benefits violated section $703(a)(1)$, even though the statistics demonstrate that women as a class live longer than men:

The statute makes it unlawful "to discriminate against any individual with respect to his compensation, terms, conditions, or privileges of employment, because of such individual's race, color, religion, sex, or national origin." ... The statute's focus on the individual is unambiguous. It precludes treatment of individuals as simply components of a racial, religious, sexual, or national class. If height is required for a job, a tall woman may not be refused employment merely because, on the average, women are too short. Even a true generalization about the class is an insufficient reason for disqualifying an individual to whom the generalization does not apply. ${ }^{105}$

The critical fact with respect to the capacity to bear children, as it was with respect to longevity in Manhart, is that there is no assurance that any individual woman will fit the generalization that exposed women will produce defective progeny. As in Manhart, the employer cannot predetermine which women will experience adverse pregnancies as the result of occupational exposure to the toxic substance and which women will not. The impossibility of identifying those who will be harmed does not alter the requirement of section $703(a)(1)$ that women be treated in employment as individuals and not as members of a class. Such a justification for disparate treatment may be relevant to the defenses under title VII but not to the applicability of section $703(\mathrm{a})(1)$.

103 The available medical evidence as to mutagens and gametotoxins (which operate on the reproductive cells) will not support a finding that females face a greater average risk of reproductive impairment. See notes 16-43 supra \& accompanying text. If the substance has purely teratogenic effects (affects the fetus directly), however, there is a theoretically greater aggregate risk to the offspring of female workers than to the offspring of male workers.

104435 U.S. 702 (1978).

105 Id. 708 (emphasis in original) (citation omitted). 


\section{d. Disparate Impact}

An employer could attempt to avoid falling under the disparate treatment standard of title VII by enacting an exclusionary policy, couched in neutral terms, that purports to respond to the health needs of employees or their unborn. An example would be a policy flatly prohibiting the employment of any fertile male or female. Assuming that such a facially neutral policy was not vulnerable to attack on grounds of pretext, it would survive scrutiny under a disparate treatment analysis.

Such a practice might not, however, escape the reach of title VII entirely. If, as implemented, it were to exclude a disproportionate number of one sex, discrimination under title VII could still be found on the ground that the practice affected one sex disproportionately from the other. ${ }^{106}$ Continuing with the example above, a policy excluding all fertile individuals would probably be subject to challenge by virtue of the medical reality that males generally remain fertile longer than females. ${ }^{107}$

Most existing examples of discrimination justified by the specter of reproductive harm are limited to practices adversely affecting women; these are so obviously discriminatory that they are easily vulnerable on disparate treatment grounds. Nonetheless, the possibility that an employer may attempt to reimplement such a policy by framing it in neutral terms must be foreseen and addressed.

\section{Rebutting the Prima Facie Case of Discrimination}

Once the plaintiff makes out a prima facie case of sex discrimination on either disparate treatment or disparate impact grounds, the burden of proof 108 shifts to the employer to, in essence, "justify" the discrimination. The standard of justification necessary is dependent on the plaintiff's prima facie case; a showing of disparate treatment on the basis of sex may be justified only by proving that sex is a "bona fide occupational qualification." Disparate impact, untainted by pretext, may be justified by proving that the policy or practice giving rise to the disparate impact is a "manifest business necessity."

108 See text accompanying notes 79-84 supra.

107 Less obvious cases of disparate impact are generally proven by resort to statistical evidence. See generally Hricko, supra note 2, at 400 . For a summary of demographic sources and statistics concerning employment during pregnancy, see J. Steuliman, supra note 16, at 139-44.

108 See notes 73, 74 \& 81 supra \& accompanying text. 


\section{a. The Bona Fide Occupational Qualification Defense}

Section 703(e) of title VII provides that "[n]otwithstanding any other provision of this subchapter, ... it shall not be an unlawful employment practice for an employer to hire and employ employees ... on the basis of ... sex . . . in those certain instances where ... sex... is a bona fide occupational qualification reasonably necessary to the normal operation of that particular business or enterprise." 109

The Supreme Court first construed the bona fide occupational qualification (BFOQ) in Dothard $v$. Rawlinson ${ }^{110}$ and held that the likelihood of sexual assault by inmates justified the employer's refusal to hire women as correctional counselors in a maximum security male prison facility. The opinion states that "the BFOQ exception was in fact meant to be an extremely narrow exception to the general prohibition of discrimination on the basis of sex," ${ }^{111}$ but the Court provided no discrete test for its application in future cases. The employer who excludes fertile women from employment could thus argue that Dothard supports the contention that a fertile woman's susceptibility to reproductive injury, or potential harm to her future children, justifies sex as a BFOQ.

The cases are, however, distinguishable on their facts. The Court in Dothard found that the risk of sexual assault to the female plaintiff justified the discrimination because it "directly undermine[d] her capacity to provide the security that is the essence of a correctional counselor's responsibility." 112 Despite serious flaws in the majority opinion, ${ }^{113}$ the Court correctly focused the inquiry on the applicant's ability to perform the essential duties of the job involved. In the absence of evidence that fertile women cannot perform the essential duties of the job, Dothard lends no support for the proposition that susceptibility of women to injury is itself a sufficient basis for the BFOQ defense.

The BFOQ defense has not enjoyed consistent interpretation by the lower courts. The standard for the bona fide occupational qualification originally developed by the Ninth Circuit Court of Appeals in Rosenfeld v. Southern Pacific Co. ${ }^{114}$ states that "sexual

10942 U.S.C. $\$ 2000 \mathrm{e}-2(\mathrm{e})(1976)$.

110433 U.S. 321 ( 1977 ).

111 Id. 334 (footnote omitted). See also 29 C.F.R. $\$ 1604.2$ (a) (1980) (EEOC Guidelines).

112433 U.S. at 336.

113 Id. 341 (Marshall, J., dissenting). See notes 173-75 infra \& accompanying text.

114444 F.2d 1219 (9th Cir. 1971). 
characteristics, rather than characteristics that might, to one degree or another, correlate with a particular sex, must be the basis for the application of the BFOQ exception." 115 Under this test, the employer must demonstrate that the performance of the job requires that the worker possess a sexual characteristic unique to the members of one sex. Even in cases in which certain biological attributes, such as physical strength, are necessary for job performance, the BFOQ exception will not justify the exclusion of all women from employment unless the employer shows that a male sexual characteristic is "crucial to the successful performance of the job" 116 involved.

The other major standard evolves from Weeks v. Southern Bell Telephone of Telegraph Co. ${ }^{117}$ and Diaz v. Pan American World Airways, Inc. ${ }^{118}$ The Weeks-Diaz standard, cited but not specifically adopted in Dothard, , $^{119}$ requires that "in order to rely on the bona fide occupational qualification exception an employer has the burden of proving that he had reasonable cause to believe, that is, a factual basis for believing, that all or substantially all women would be unable to perform safely and efficiently the duties of the job involved." 120 In addition, the employer must demonstrate that the particular duties of the job involved are necessary to the employer's business to the extent that "the essence of the business operation would be undermined by not hiring members of one sex exclusively." 121

115 Id. 1225.

The Ninth Circuit may have recently abandoned its own test, see Harriss v. Pan Am. World Airways, Inc., 24 Empl. Prac. Dec. $\int 31,425$ (9th Cir. 1980), in favor of the Weeks-Diaz standard discussed at text accompanying notes 117-22 infra. This would leave the Seventh Circuit as the only circuit explicitly endorsing the Rosenfeld test. See In re Consolidated Pretrial Proceedings in the Airline Cases, 582 F.2d 1142, 1146 (7th Cir. 1978), cert. granted sub nom. Zipes v. Trans World Airlines, Inc., 49 U.S.L.W. 3663 (U.S. Mar. 10, 1981) (No. -78-1545).

116 Rosenfeld, 444 F.2d at 1224.

117408 F.2d 228 (5th Cir. 1969).

118442 F.2d 385 (5th Cir.), cert. denied, 404 U.S. 950 (1971).

119433 U.S. at 333.

120 Weeks, 408 F.2d at 235.

121 Diaz, 442 F.2d at 388 (emphasis in original).

The most concise formulation of the Weeks-Diaz test is as follows:

[A]n employer asserting a BFOQ defense has the burden of showing (1) that its policy " . . is reasonably necessary to the essence of its business . . .", and that (2) the employer has ". . a factual basis for believing that all or substantially all persons within the class ... . would be unable to perform safely and efficiently the duties of the job involved, 
In Diaz, the source of the "essence of the business" requirement, the Fifth Circuit considered the airline's refusal to hire males as flight attendants. The court rejected as a basis for the BFOQ the employer's assertion that all or substantially all men lacked the ability to make its passengers feel safe and comfortable, saying that the nonmechanical aspects of the job were tangential and not "reasonably necessary to the normal operation" of the employer's business. ${ }^{122}$

The two standards differ primarily in that the Weeks-Diaz standard would appear to permit the employer to exclude all women from a job when some women are fully capable of performing. Under the Rosenfeld standard, unless the employer can demonstrate that a male or female sex characteristic is necessary to the employer's business, title VII requires an individual evaluation of ability to perform. ${ }^{123}$

Employers who exclude all fertile women but no fertile men can assert three possible justifications for such a practice: (1) the practice prevents harm to the female employee; (2) the practice prevents harm to the fetus, or (3) the practice avoids the cost of liability to the worker and a subsequently conceived child if the worker suffers an adverse pregnancy caused by exposure to the toxic substance, and avoids the cost of developing and implementing technology that would reduce the risk of reproductive harm from exposure to the toxic substance. These objectives for excluding women with childbearing capacity satisfy neither of the established tests for the BFOQ.

or that it is impossible or impractical to deal with persons ... on an individualized basis. ...."

Burwell v. Eastern Air Lines, Inc., 458 F. Supp. 474, 497 (E.D. Va. 1978) (quoting Arritt v. Grisell, 567 F.2d 1267, 1271 (4th Cir. 1977)), aff'd in part and rev'd in part per curiam, 633 F.2d 361 (4th Cir. 1980), cert. denied, 49 U.S.L.W. 3643 (U.S. Mar. 3, 1981) (Nos. 80-868 \& 80-1076).

At least one court has focused upon the essence of the job in question rather than the essence of the business. See, e.g., Fesel v. Masonic Home of Delaware, Inc., 428 F. Supp. 573, 578 (D. Del. 1977). This is a disturbing development because it might permit an employer to define the position in sexist terms-for example, airline cabin attendants must be "maternal"-and thus render sex a valid BFOQ. The Diaz "essence of the business" test forecloses this result unless the business itself is sexist. See Sirota, supra note 76, at 1066-70.

122 Diaz, 442 F.2d at 388.

${ }^{123}$ The Rosenfeld standard, with its narrower construction, is the more appropriate choice. Consistent with the policy behind title VII, it mandates that employers "eliminate subjective assumptions and traditional stereotyped conceptions regarding the physical ability of women to do particular work." 444 F.2d at 1225. Conversely, the Weeks-Diaz standard permits the employer to exclude all women from employment upon a showing that substantially all women cannot perform the job, thus denying employment opportunities to women who are qualified. The "substantially all women" standard is vague, moreover, and thus allows employers to be much more subjective in their hiring policies. 
(i) Risk of Harm to the Worker

Although the capacity to become pregnant does not itself affect job performance, the employer could assert that the likelihood of injury to the worker makes sex or infertility a bona fide occupational qualification. It must be kept in mind that the risk of harm that the employer would be asserting would not be immediate and incapacitating, but rather, as in the case of lead poisoning, ${ }^{124}$ insidious and not necessarily incapacitating in the short run. In these circumstances, in which the hazard does not incapacitate or otherwise adversely affect the employee's performance on the shop floor, the risk of harm to the employee is not relevant to any possible BFOQ defense.

Nowhere is this principle better illustrated than in early cases striking down sex-based exclusions otherwise justified by state "protective labor laws." Rosenfeld v. Southern Pacific Co., ${ }^{125}$ for example, raised the issue whether a state law prohibiting the employment of women to lift weights in excess of fifty pounds or to labor more than ten hours per day justified the employer's refusal to hire women workers. The court found that the BFOQ defense "establishes a narrow exception inapplicable where, as here, employment opportunities are denied on the basis of characterizations of the physical capabilities and endurance of women, even when those characteristics are recognized in state legislation." 126

A plethora of federal and state court decisions have reached the same result and invalidated state protective labor laws that prohibited women from working in particular jobs or limited the weights that women may lift, the maximum number of hours they may work, the time of day they may work, and the amount of work they may do prior to childbirth. ${ }^{127}$ The thrust of these laws-pro-

124 See text accompanying notes 21-24 supra.

125444 F.2d 1219 (9th Cir. 1971).

128 Id. 1227. See also 29 C.F.R. \$1604.2(b) (1980).

127 See, e.g., Krause v. Sacramento Inn, 479 F.2d 988 (9th Cir. 1973) (job prohibition law); Evans v. Sheraton Park Hotel, 5 Fair Empl. Prac. Cas. 393 (D.D.C. 1972) (hours law); LeBlanc v. Southern Bell Tel. \& Tel. Co., 333 F. Supp. 602 (E.D. La. 1971) (hours law), affd on other grounds, 460 F.2d 1228 (5th Cir.), cert. denied, 409 U.S. 990 (1972); Kober v. Westinghouse Elec. Corp., 325 F. Supp. 467 (W.D. Pa. 1971) (hours law), aff'd, 480 F.2d 240 (3d Cir. 1973); Ridinger v. General Motors Corp., 325 F. Supp. 1089 (S.D. Ohio 1971) (job prohibition, weight and hour laws), remanded on other grounds, 474 F.2d 949 (6th Cir. 1972); Garneau v. Raytheon Co., 323 F. Supp. 391 (D. Mass. 1971) (hours law); General Elec. Co. v. Young, 3 Fair Empl. Prac. Cas. 560 (W.D. Ky. 1971) (hours law); Rinehart v. Westinghouse Elec. Corp., 3 Fair Empl. Prac. Cas. 851 (N.D. Ohio 1971) (job prohibition and weight laws); Manning v. General Motors Corp., 3 Fair Empl. Prac. Cas. 968 (N.D. Ohio 1971) (job prohibition, weight and hour laws), aff'd on other grounds, 466 F.2d 812 (6th Cir. 1972), cert. 
tecting women as a class from dangerous or hazardous employmentviolates the letter as well as the policy of title VII, which requires individual rather than class considerations in employment decisions. It certainly stands to reason that if the state, with its broad legislative power, may not lawfully "protect" women from dangerous jobs on the basis of their supposed capabilities and endurance, then the individual employer also lacks the power under title VII to promulgate an exclusionary policy for the same purpose and on the same basis. ${ }^{128}$

It might appear ironic that employee health is not a sufficient justification for discrimination. The following passage from Weeks v. Southern Bell Telephone \& Telegraph Co..$^{129}$ places this apparent irony in its proper perspective:

Title VII rejects ... . romantic paternalism as unduly Victorian and instead vests individual women with the power to decide whether or not to take on unromantic tasks. Men have always had the right to determine whether the incremental increase in remuneration for strenuous, dan-

denied, 410 U.S. 946 (1973); Local 246, Utility Workers Union v. Southern Cal. Edison Co., 320 F. Supp. 1262 (C.D. Cal. 1970) (weight law); Caterpillar Tractor Co. v. Grabiec, 317 F. Supp. 1304 (S.D. III. 1970) (hours law); McCrimmon v. Daley, 2 Fair Empl. Prac. Cas. 971 (N.D. Ill. 1970) (job prohibition law); Richards v. Griffith Rubber Mills, 300 F. Supp. 338 (D. Ore. 1969) (weight law); Sail'er Inn, Inc. v. Kirby, 5 Cal. 3d I, 485 P.2d 529, 95 Cal. Rptr. 329 (1971) (job prohibition law); Jones Metal Prods. Co. v. Walker, 29 Ohio St. 2d 173, 281 N.E.2d 1 (1972) (hours, weight and job prohibition laws).

128 See Dothard v. Rawlinson, 433 U.S. 321, 335 (1977).

Although most state protective laws have been struck down or rescinded, there continutes to be a litany of cases invalidating sexually discriminatory employer policies purportedly justified by a safety risk to the female employee. See, e.g., Burwell v. Eastern Air Lines, Inc., 458 F. Supp. 474, 497 (E.D. Va. 1978) (concern for the health and welfare of its flight attendant, albeit laudatory, does not touch upon the essence of the airline's business), aff'd in part and rev'd in part per curiam, 633 F.2d 361 (4th Cir. 1980), cert. denied, 49 U.S.L.W. 3643 (U.S. Mar. 3, 1981) (Nos. 80-868 \& 80-1076); Maclennan v. American Airlines, Inc., 440 F. Supp. 466 (E.D. Va. 1977) (that some female flight attendants might be incapacitated by pregnancy does not establish sex as a BFOQ); Ruckel v. Essex Int'l, Inc., 14 Fair Empl. Prac. Cas. 403 (N.D. Ind. 1976) (mere fact that all sixteen women to whom heavy industrial jobs were offered turned them down does not make sex a BFOQ). Cases upholding similar policies, such as Harriss v. Pan Am. World Airways, Inc., 24 Empl. Prac. Dec. I 31,425 (9th Cir. 1980) and Condit v. United Air Lines, 558 F.2d 1176 (4th Cir. 1977), cert. denied, 435 U.S. 934 (1978), are distinguishable because they rely upon a finding of a safety risk to a third party. See note 188 infra; Usery v. Tamiami Trail Tours, Inc., 531 F.2d 224 (5th Cir. 1976). Nor does the Supreme Court's allowance of an exclusion of women from the position of high-security prison guard in Dothard $v$. Rawlinson, 433 U.S. 321 (1877), undermine this principle. Although the risk of sexual assault upon the female guard was a factor in the Court's analysis, it was relevant only in so far as it impacted on the ability of the female guard to perform the essential duties of a "correctional counselor." Id. 335-36. But see text accompanying notes 173-75 infra.

129408 F.2d 228 (5th Cir. 1969). 
gerous, obnoxious, boring or unromantic tasks is worth the candle. The promise of title VII is that women are now to be on equal footing. ${ }^{130}$

The message simply is that if men are permitted to assume the risk of unhealthful employment, so too should women. ${ }^{131}$

(ii) Risk of Harm to the Unborn

The next major issue is whether the employer's concern for the health of the future children of its workers justifies the establishment of sex as a bona fide occupational qualification. Under a principled application of either the Weeks-Diaz or Rosenfeld standard, such a showing would be impossible. If one applies the WeeksDiaz test, it is obvious that the state of health of the employee's unborn in no way "touches the essence" of the employer's business. The Rosenfeld standard fares no better. For although the capacity to become pregnant is a unique physical characteristic, the inability to conceive a normal child is not "crucial to the successful performance" of the employee's job. ${ }^{132}$ Simply stated, the mere fact that a workplace hazard has affected the female employee's capacity to bear healthy children does not necessarily affect her ability to work. Thus, under either the Weeks-Diaz or Rosenfeld standard, the necessary nexus between the health of the unborn child and the employee's job or employer's business does not exist.

Even if the health of the unborn could be taken into account, under the Weeks-Diaz test it would be particularly difficult for the employer to prove that "all or substantially all" fertile women risk producing unhealthy children because of workplace exposure to toxic substances. For various reasons, a substantial number of

130 Id. 236.

131 See also Dothard v. Rawlinson, 433 U.S. 321, 335 (1977) ("[T]he argument that a particular job is too dangerous for women may appropriately be met by the rejoinder that it is the purpose of Title VII to allow the individual woman to make that choice for herself.") (footnote omitted).

132 Admittedly, an employer could argue that ancillary problems caused, for example, by the employee's having to care for her defective child-such as increased absenteeism and anxiety-may adversely affect her job performance. Whether or not this is true as a factual matter, it is not determinative. It may be assumed that there are many mothers who have given birth to defective children who are productive members of the work force. Thus, not bearing such a child is not "crucial" to successful job performance. Cf. In re Consolidated Pretrial Proceedings in the Airline Cases, 582 F.2d 1142, 1146-47 (7th Cir. 1978) (that mother's concern for her children might affect her job performance is not enough to establish sex as a BFOQ under Rosenfeld), cert. granted sub nom. Zipes v. Trans World Airlines, Inc., 49 U.S.L.W. 3663 (U.S. Mar. 10, 1981) (No. 78-1545). But cf. Phillips v. Martin Marietta Corp., 400 U.S. 542, 544 (1971) (per curiam) (remanding for further findings of fact as to whether "conflicting family obligations" of mothers with children makes sex a BFOQ). 
women with childbearing capacity will never become pregnant. Of those who do conceive, many will give birth to healthy children. Therefore, the "all or substantially all" leg of the Diaz test could not be met.

The only case to face the issue squarely, ${ }^{133}$ Burwell $v$. Eastern Air Lines, Inc., ${ }^{134}$ supports this analysis. Burwell rejected the employer's argument that its asserted interest in the health of the flight attendant's future child justified its policy of placing pregnant attendants on indefinite leave. The court stated that the employer "cannot rest its BFOQ defense on its concern for the health and welfare of flight attendants and their unborn children. Such concerns are laudatory, but do not touch upon the essence of [the employer's] business." 135

\section{(iii) Cost to the Employer}

The final question to ask in relation to the BFOQ defense is whether the employer could successfully argue that the costs associated with hiring fertile women justify sex as a bona fide occupational qualification. Such costs would include (l) the cost of increased insurance premiums or tort liability to compensate for possible harm to the employee's reproductive system; ${ }^{136}$ (2) possible

133 Some courts appear to have assumed that the risk of fetal harm is an appropriate consideration when that issue was not necessary to decide the case. See, e.g., Doerr v. B.F. Goodrich Co., 484 F. Supp. 320, 326 \& n.4 (N.D. Ohio 1979). In fact, in Doerr, a case in which an employee challenged B.F. Goodrich's policy of excluding women from jobs involving vinyl chloride, see note 11 supra, the court indicated that the employer would probably prevail on the merits if the merits were reached. 484 F. Supp. at 326.

134458 F. Supp. 474 (E.D. Va. 1978), affd in part and rev'd in part per curiam, 633 F.2d 361 (4th Cir. 1980), cert. denied, 49 U.S.L.W. 3643 (U.S. Mar. 3,1981 ) (Nos. 80-868 \& 80-1076).

135 Id. 497.

136 Compensation for occupational injury generally comes from a state's workers' compensation fund. See 4 A. Larson, ThE Law of Workman's Compensation $\$ 92.10$ (1980). It is not clear, however, that a woman suffering harm to her reproductive system caused by an unhealthful workplace could recover workers' compensation benefits. Workers' compensation usually covers only injuries that interfere with the worker's effectiveness on the job. 2 A. LARson, supra, at $\$ 57$. Reproductive harm is not generally of this type. See 2A A. Larson, supra at $\$ 65.20$.

If the injury is not covered by the state's workers' compensation law, the employee may have a common law cause of action in tort. Recovery is not necessarily forthcoming here, either. Unless the employer is held liable on a no-fault principle, see, e.g., Restatement (Second) of Torts \$519 (1977) (imposing absolute liability for certain "abnormally dangerous" activity), he would probably be able to interpose an assumption of risk or contributory negligence defense if the employee had been adequately warned of the hazard. Id. $\$ \$ 523,524$. See also text accompanying notes 129-30 supra. 
liability arising from tortious injury to the unborn child, ${ }^{13 \pi}$ and (3) the cost, should the employer be required to bear it, of lowering the workplace exposure levels of the toxin in question so as to reduce or eliminate the risk of injury. Note that this question is not the same as asking whether harm to the employee or her unborn is in itself relevant to the establishment of a BFOQ defense. The difference here is that now the costs associated with such harm have been absorbed into the employer's costs of doing business. In this manner, harm to the worker and her unborn may in fact become relevant to the "essence" of the employer's business.

It could be argued that the Supreme Court has already decided that cost is never relevant to the establishment of a BFOQ defense. In City of Los Angeles Department of Water and Power v. Manhart, ${ }^{138}$ the employee-plaintiffs claimed that the employer's practice of exacting larger contributions towards a pension plan from women than from men constituted unlawful discrimination under title VII. The employer argued, inter alia, "that the prima facie showing of discrimination based on evidence of different contributions for the respective sexes is rebutted by its demonstration that there is a like difference in the cost of providing benefits for the respective classes." 139 The Court rejected this argument outright: "That argument might prevail if Title VII contained a costjustification defense comparable to the affirmative defense available in a price discrimination suit. But neither Congress nor the courts have recognized such a defense under Title VII." ${ }^{140}$ The Court thus held that title VII does not permit a cost-based defense to a showing of unlawful discriminatory employment practices.

137 The question of liability for injury to unborn and unconceived children is a mare's nest of confusion and uncertainty. Generally, the defendant may be liable for injuries resulting in the disability to or death of a live-born infant or the prenatal death of a viable fetus, if such injuries were caused by defendant's wrongful act or omission. Those jurisdictions that have considered the issue have concluded that a cause of action will lie for both post- and preconception acts. See Bergstresser v. Mitchell, 577 F.2d 22 (8th Cir. 1978); Jorgensen v. Meade, 483 F.2d 237 (10th Cir. 1978); Renslow v. Mennonite Hosp., 67 Ill. 2d 348, 367 N.E.2d 1250 (1977). See generally, e.g., Morrison, Torts Involving the Unborn: A Limited Cosmology, 31 BayLor L. Rev. 131 (1979); Robertson, Toward Rational Boundaries of Tort Liability for Injury to the Unborn: Prenatal Injuries, Preconception Injuries and Wrongful Life, 1978 Dose L.I. 1401; Note, Torts Prior to Conception: A New Theory of Liability, 56 NEB. L. REv. 706 (1977); Note, The Law and the Unborn Child: The Legal and Logical Inconsistencies, 46 Norre DaMe L. Rev. 349 (1971); Note, Recovery for Prenatal Injuries: The Right of a Child Against Its Mother, 10 Suffork L. REv. 582 (1976).

138435 U.S. 702 (1978). See also text accompanying notes 104-05 supra.

139435 U.S. at 716.

140 Id. 716-17 (footnotes omitted). 
Manhart, however, does not completely dispose of the matter. After all, Manhart dealt with the relatively tractable cost of contribution to an employee pension plan. There is perhaps some: point at which the issue of cost transcends "mere" cost in such a fashion as to completely undermine the employer's business. Civil liability for a defective child, for example, could be ruinous for a small employer. At this point, cost might be considered relevant as a $\mathrm{BFOQ}$ defense. . $^{14 x}$

Even if cost were, theoretically, relevant to the BFOQ defense, it is unlikely that the employer could justify the exclusion of fertile women, and not fertile men, from the workplace. For one thing, the potential liability of the employer for the worker's impairment is not determined by the worker's sex. The employer cannot choose to avoid the cost of liability to a female applicant (or her unborn) and assume the cost of liability to a male employee for a similar injury without violating section 703(a)(2) of title VII. ${ }^{142}$ Even in those cases in which the toxic substance affects only the female reproductive system, the employer cannot choose, among the costs of all injuries faced by his workers, to avoid only the costs associated with a risk of injury faced by his female applicants or employees.

These arguments aside, it is unlikely that cost as such can or should ever constitute a BFOQ defense to disparate treatment. The fact remains that cost of labor in no way affects the employee's literal ability to perform the job. Basic economic terms such as cost simply do not mesh neatly with the concept of an occupational qualification. ${ }^{143}$ At the moment, then, the best course may be to take Manhart at its word: explicit, intentional sex discrimination can never be justified by reference to the employer's costs. The employer will therefore be unable to defend an exclusion of fertile women using the BFOQ defense.

\section{b. The Manifest Business Necessity Defense}

In contrast to the statutory BFOQ defense, the judicially created manifest business necessity defense is available only when an employer's gender-neutral employment policy is shown to have a disparate impact on the members of one sex. This defense would

141 And, in fact, the use of the word "impractical" in the current formulation of the Weeks-Diaz test, see note 121 supra, would suggest some room for a costbased BFOQ defense. But see Sirota, supra note 76, at 1052 n.I64.

14242 U.S.C. $\$ 2000 \mathrm{e}-2(\mathrm{a})(2)(1976)$.

143 Rather, the idea of cost appears more compatible with the manifest business necessity defense. See text accompanying notes 159-64 infra. 
be available-if at all-only if the employer demonstrates that the harmful reproductive effects of occupational exposure to the toxin are confined to women and their offspring. Any similar effect on men would render the policy facially discriminatory.

First adopted by the Supreme Court in the race discrimination case of Griggs v. Duke Power Co. ${ }^{144}$ and later applied to sex discrimination in Dothard $v$. Rawlinson, ${ }^{145}$ the manifest business necessity defense imposes upon the employer " 'the burden of showing that any given requirement [has] . . a a manifest relationship to the employment in question.' "146 Furthermore, under the Dothard formulation, even if the employer proves the requisite degree of job-relatedness, the plaintiff may rejoin by showing the availability of other practices or policies "without a similar discriminatory effect [which] would also 'serve the employer's legitimate interest in "efficient and trustworthy workmanship." " 147 Under current title VII law, none of the employer's possible justi-

144401 U.S. 424 (1971).

145433 U.S. 321 (1977).

146 Id. 329 (quoting Griggs v. Duke Power Co., 401 U.S. 424 (1971)).

Under the manifest business necessity defense, the employer need not prove that the protected class, as a class, is unqualified to perform. Thus the employer's burden under manifest business necessity is somewhat lighter than his burden under the BFOQ defense.

Some courts have wrongly allowed employers to justify their employment policies under both the $\mathrm{BFOQ}$ and manifest business necessity defenses when only one defense was appropriate. See, e.g., Burwell v. Eastern Air Lines, Inc., 458 F. Supp. 474, 495 (E.D. Va. 1978), affd in part and rev'd in part per curiam, 633 F.2d 361 (4th Cir. 1980), cert. denied, 49 U.S.L.W. 3643 (U.S. Mar. 3, 1981) (Nos. 80-868 \& 80-1076). Clearly, if the employer's policy constitutes disparate treatment, his justification should be carefully limited to the statutory BFOQ defense; any more generous treatment by the courts only serves to undermine title VII.

147 Dothard, 433 U.S. at 329 (quoting Albemarle Paper Co. v. Moody, 422 U.S. 405, 425 (1975) (in turn quoting McDonnell Douglas Corp. v. Green, 411 U.S. 792,801 (1973))).

Some courts prefer a somewhat different formulation of this test:

The test is whether there exists an overriding legitimate business purpose such that the practice is necessary to the safe and efficient operation of the business. Thus, the business purpose must be sufficiently compelling to override any racial impact; the challenged practice must effectively carry out the business purpose it is alleged to serve; and there must be available no acceptable alternative policies or practices which would better accomplish the business purpose advanced, or accomplish it equally well with a lesser differential racial impact.

Robinson v. Lorillard Corp., 444 F.2d 791, 798 (4th Cir.), cert. dismissed, 404 U.S. 1006 (1971), quoted in Burwell v. Eastern Air Lines, Inc., 633 F.2d 361, 371 (4th Cir. 1980) (per curiam) (footnote omitted), cert. denied, 49 U.S.L.W. 3643 (U.S. Mar. 3, 1981) (Nos. 80-868 \& 80-1076).

The two tests probably yield like results when applied. A crabbed reading of the Supreme Court's version, however, might suggest that there exists only one business interest "sufficiently compelling to override any [sexual] ... impact"the employer's interest in "efficient and trustworthy workmanship." 
fications-health of the female employee, her unborn, or the costs of following any policy besides one resulting in exclusion ${ }^{148}$-would likely survive scrutiny under this standard.

(i) Risk of Harm to the Worker

The employer could assert that harm to the female employee's reproductive system in itself justifies a facially neutral policy that results in the exclusion of a disproportionate number of women from employment. As in the context of the BFOQ defense, ${ }^{149}$ it is doubtful that employee health, without more, suffices as an overriding legitimate business interest under the manifest business necessity test. Some courts have been reluctant to deem any other business interest than job performance as an "overriding legitimate" interest under this test. In Johnson v. Pike Corp. of Amer$i c a,{ }^{180}$ for example, it was the employer's policy to discharge employees whose wages were garnished several times. The employer argued that repeated wage garnishments raised its business costs and resulted in a loss of business efficiency, thus justifying the disproportionate effect of the policy on black employees. The district court held that

[t]he sole permissible reason for discriminating against actual or prospective employees involves the individual's capability to perform the job effectively. This approach leaves no room for arguments regarding inconvenience, annoyance or even expense to the employer. . . . The ability of the individual effectively and efficiently to carry out his assigned duties is, therefore, the only justification recognized by law. ${ }^{151}$

Gertainly, employee health transcends "inconvenience, annoyance or . . expense." Nonetheless, the same reasoning that was used to invalidate the employer's policy in Johnson has also been applied in the context of employee health. In Burwell v. Eastern Air Lines, Inc., ${ }^{152}$ the employer airline put forth the increased physical risk to the employee as one reason for not permitting pregnant flight attendants to fly. Responded the court:

148 See text following note 123 supra.

149 See notes 124-31 supra \& accompanying text.

150332 F. Supp. 490 (C.D. Cal. 1971).

151 Id, 495-96.

152633 F.2d 361 (4th Cir. 1980) (per curiam), cett. denied, 49 U.S.L.W. 3643 (U.S. Mar. 3, 1981) (Nos. 80-868 \& 80-1076). 
Eastern's contention that an element of business necessity is its consideration for the safety of the pregnant flight attendant . . . is not persuasive. If this personal compassion can be attributed to corporate policy it is commendable, but in the area of civil rights, personal risk decisions not affecting business operations are best left to individuals who are the targets of discrimination..$^{153}$

Thus the question of maternal health is relevant only in so far as it has a "manifest relationship to the employment in question." Given the assumption that the workplace health hazard harms only the reproductive system, this nexus, as argued previously in the context of disparate treatment analysis, ${ }^{154}$ would be nearly impossible to establish. ${ }^{155}$

\section{(ii) Risk of Harm to the Unborn}

The assertion that the health of the employee's unborn is an overriding legitimate business interest for the purposes of disparate impact analysis meets the same fate as the claim respecting the health of the employee-the purported justification simply has no legally recognizable relationship to the employer's business, and thus it can not justify the discrimination. ${ }^{166}$ This interest was rejected as overriding in In re National Airlines, Inc. Maternity Leave Practices and Flight Attendant Weight Program Litigation, ${ }^{167}$ in which the airline, as in Burwell, sought to exclude pregnant employees from flight duty. Although the employer's defense failed for lack of proof that flight duty was hazardous to the health of the unborn child, the court stated that in any case decisions as to the health of the fetus belong to the mother, not to the employer. ${ }^{158}$

153 Id. 371.

164 See notes 124-31 supra \& accompanying text.

156 But of. Harriss v. Pan Am. World Airways, Inc., 24 Empl. Prac. Dec. If 31,425 (Oth Cir. 1980) (nonpregnancy held to be a BFOQ). See note 128 supra.

156 See notes 132-35 supra \& accompanying text.

157434 F. Supp. 249 (S.D. Fla. 1977).

158 Id. 259. See also Burwell, 633 F.2d at 371. The Equal Employment Opportunity Commission (EEOC) has avoided taking a stance on this issue. See EEOC Decision No. 75-072, EEOC Dec. If 6442 (1974); EEOC Decision No. 75-055, EEOC Dec. $\llbracket 6443$ (1974). These cases were initiated by pregnant x-ray technicians who were required by their employers to resign without benefits to avoid possible injury to their unborn children from exposure to ionizing radiation. In both decisions, the Commission skirted the question whether preserving the health of the employees' unborn children is a compelling business purpose but concluded that, even if the employer could establish that fetal health is a compelling business purpose, that purpose was not so compelling as to justify forcing 


\section{(iii) Cost to the Employer}

If Johnson v. Pike Corp. of America ${ }^{159}$-which held that job performance is the only employer interest considered legitimate under the manifest business necessity test-is limited to its facts, an employer might succeed in persuading the court that the costs associated with nonexclusion make exclusion a manifest business necessity. ${ }^{160}$ Those costs would include the expenses incurred if the employer is held liable for harm to the employee's reproductive system ${ }^{161}$ and possibly to her unborn. ${ }^{162}$ Note that these expenses are not the "incidental" costs generally associated with the elimination of discrimination, which the employer is required to bear. ${ }^{103}$ Rather, the liability imposed could be crippling, and, at least for small businesses, could threaten the employer's immediate solvency and ongoing profitability. If the relationship between liability and profitability and/or solvency was sufficiently "manifest," a court could hold that the avoidance of such costs by means of an exclusionary policy might be a purpose sufficiently compelling to outweigh the policy's discriminatory impact. ${ }^{164}$

No court has ever accepted such an argument. But even if the employer successfully persuades the court of the existence of a costbased defense, his victory is likely to be hollow. The plaintiff can

the pregnant women to resign their jobs without benefits when other, more acceptable alternatives existed.

159332 F. Supp. 490 (C.D. Cal. 1971).

160 See generally Note, Business Necessity Under Title VII of the Civil Rights Act of 1964: A No-Alternative Approach, 84 YAxE L.J. 98 (1974). But see City of Los Angeles Dep't of Water \& Power v. Manhart, 435 U.S. 702, 716-17 (1978).

161 See note 136 supra.

162 See note 137 supra.

163 See, e.g., City of Los Angeles Dep't of Water \& Power v. Manhart, 435 U.S. 702 (1978) (pension plan contribution differential); Hutchinson v. Lake Oswego Sch. Dist. No. 7, 519 F.2d 961, 966 (9th Cir. 1975) (administrative costs), cert. denied, 429 U.S. 1037 (1977); United States v. N.L. Indus., Inc., 479 F.2d 354, 366 \& n.11 (8th Cir. 1973) (training costs); Robinson v. Lorillard Corp., 444 F.2d 791, 800 (4th Cir.) (costs of altering employment practices, specifically, a seniority system), cert. dismissed, 404 U.S. 1006 (1971); 29 C.F.R. $\$ 1604.9$ (e) (1980) (pension plan costs).

164 See Bing v. Roadway Express, Inc., 444 F.2d 687, 690 (5th Cir. 1971) (dictum); cf. 45 C.F.R. $\$ 84.12$ (1980) (costs will be considered as a defense to a charge of discrimination against the handicapped to the extent that they impose an "undue hardship").

One student commentator has suggested that costs that would put the individual employer out of business would satisfy the manifest business necessity defense. See Colom. Note, supra note 15, at 147, 151-52. But cf. Sirota, supra note 76, at $1052 \mathrm{n} .164$ (counselling against a "business failure avoidance" BFOQ).

The answer that an employer can always buy insurance is an answer, but not a complete one. The premiums alone could be onerous, especially if the insurance pool was small. 
respond by employing the second leg of the Dothard test. She may posit the existence of less discriminatory alternatives than a policy of wholesale exclusion. The Equal Employment Opportunity Commission accepted such a rejoinder in two cases in which the employer asserted possible radiation harm to the fetuses of pregnant x-ray technicians as a justification for terminating pregnant technicians. ${ }^{165}$ " $[R]$ espondent [employer] has failed to show why it could not have given [the employee] a leave of absence or why she could not have been allowed to use her sick leave or maternity benefits." 166

In the context of some chemical hazards, temporary measures such as these would probably not be sufficient because the harmful effects on the mother may commence before she is pregnant, ${ }^{167}$ and the harmful effects on the fetus may be most pronounced before the mother is even aware that she is pregnant. ${ }^{168}$ In these situations, the employer might reduce the concentration of the toxin to levels at which neither the mother nor her unborn is at risk, or remove the worker periodically from the toxic environment so that her body can rid itself of the toxin. ${ }^{168}$

Under current law, it is unlikely that the court would ever reach the issue of less discriminatory alternatives. As the foregoing discussion has demonstrated, none of the employer's possible justifications for exclusion-employee health, fetal health, or excessive cost-constitutes a compelling business interest. Thus-assuming correct application of title VII-the employer's defense will fail, the exclusionary policy will be invalidated, and the employee will be ordered back on the job. No discussion of alternatives will be necessary. ${ }^{170}$

\section{THE NEED FOR REFORM}

The preceding analysis strictly applied title VII to the issue of exclusion of fertile women from the workplace. The ineluctable conclusion of such analysis-that title VII forbids exclusion from the

165 See EEOC Decision No. 75-072, EEOC Dec. I6442 (1974); EEOC Decision No. 75-055, EEOC Dec. $\llbracket 6443$ (1974).

168 EEOC Decision No. 75-072, EEOC Dec. I6442, at 4181 (1974).

167 See text accompanying notes 18-19 supra \& accompanying text.

168 See note 43 supra \& accompanying text.

169 OSHA's lead standards require just such periodic removal. See 29 C.F.R. $\$ 1910.1025$ (1980).

170 The proposal articulated later in this Article, see notes 191-254 infra \& accompanying text, allows exclusion in some limited circumstances. In such cases, the examination of less discriminatory alternatives becomes a crucial concern. The subject is discussed at greater length at notes 220-31 infra \& accompanying text. 
hazardous workplace-leads, however, to two related problems. First, faced with the harshness of the result, courts may shy away from disciplined title VII analysis altogether, and allow the employer broad power to exclude. Second, even proper application of current title VII law does not solve the disturbing problem of reproductive hazards in the workplace. Clearly, new standards are thus required if the courts are to avoid these two pitfalls. The discussion below illustrates this need for reform.

\section{A. The Temptation to Weaken Title VII}

If title VII is correctly applied, the employer will be unable to justify its refusal to hire fertile or pregnant women, and the successful plaintiff will demand relief. The dilemma facing the courts is that the traditional title VII remedies-reinstatement and backpay ${ }^{171}$-will eliminate only the unlawful discrimination. They will not protect mother, father, or future child from health risks associated with hazardous substances.

Faced with such a difficult and painful choice, the court may well forego strict application of title VII and attempt to solve the overriding health problem by permitting the employer to exclude women with childbearing capacity. Unwilling to risk reproductive injury to women, the court may simply ignore or misapply the principle that the decision as to whether a woman will engage in dangerous, inconvenient, or unromantic employment belongs to the woman and not to the employer or the court. ${ }^{172}$

This is not merely a theoretical concern; even the Supreme Court has demonstrated substantial difficulty in maintaining a disciplined analysis when faced with the possibility of sexual harm to women. In Dothard $v$. Rawlinson, ${ }^{173}$ for example, the Court assumed that female prison guards were unable to perform their duties because of the risk of assault. The opinion reveals the ease with which the Court can rely upon assumptions about the relative abilities of women to perform a particular job rather than upon the factual evidence in the record.

For one thing, there was no evidence in the record beyond the opinions of male guards and other employees of the defendant that female guards are more vulnerable to attack and generally less.

171 See 42 U.S.C. $\$ 2000 \mathrm{e}-5$ (g) (1976).

172 See text accompanying notes 130-31 supra.

173433 U.S. 321 ( 1977 ). 
effective than are male guards. ${ }^{174}$ Second, even assuming the vulnerability of some women to sexual attack, the majority opinion points to no evidence that all (or substantially all) women would be so incapacitated as to be unable to perform. Instead of assessing the individual female's abilities, the Dothard majority found that the plaintiff's "very womanhood" so increased the likelihood of an assault that it undermined her ability to maintain prison security. ${ }^{175}$

The Dothard case is admittedly distinguishable from cases involving the exclusion of fertile women from employment. The risk of reproductive harm, unlike the risk of assault, is not even arguably related to job performance. Dothard is telling, nonetheless, for it suggests that the taboos and stereotypes still inherent in our society can too easily be invoked to erode title VII and the policy of nondiscrimination.

The dangers that would attend such an inappropriate legal analysis under title VII are many. The vitality and cohesiveness of sex discrimination law would be ill-served by the creation of bad law in this highly technical and newly emerging area. Perhaps most important, if the employer is permitted to avoid the possibility of adverse pregnancies by refusing to hire fertile woman workers, he effectively escapes his statutory obligation to maintain a safe workplace. The employer thus avoids both the duty to provide equal employment opportunities and the concurrent duty, under the $\mathrm{OSH}$ Act, ${ }^{178}$ to implement technologies that assure a workplace free from recognized hazards.

\section{B. The Nagging Dilemma: Protecting the Unborn}

Unfortunately, even a correct and disciplined resolution of the legal issues that arise under title VII does not solve the disturbing problem of reproductive hazards in the workplace. The guarantee of equal employment opportunity embodied in title VII prohibits employers from excluding only women workers from employment because of their capacity to bear children. There is nothing wrong with this result as long as the employer is expected to eliminate the hazard in question as well as cease the discrimina-

174 Id. 342-45 (Marshall, J., dissenting). The success of other states in employing female guards in male facilities was dismissed. Id. 341 (Marshall, J., dissenting). Nor does the majority mention the adequacy of training in self-defense and assertiveness for female guards.

$175 \mathrm{Id} .336$.

17829 U.S.C. $\$ 654$ (a) (1976) provides: "Each employer shall furnish to each of his employees employment and a place of employment which are free from recognized hazards that are causing or are likely to cause death or serious physical harm to his employees" (emphasis added). 
tion against women. The problem arises when elimination of the hazard to women or their offspring is not a legal or practical possibility. In these cases, the employer would be required to hire workers for jobs posing a substantial risk to their reproductive health or the health of their unborn without being under any commensurate legal duty to eliminate the hazard. ${ }^{177}$

Some may argue that this is an acceptable price to pay for the removal of all sex-related barriers to employment. They may assert that it is romantic paternalism to attempt to protect women from health risks, no matter how grave. ${ }^{178}$ Further, the fact that the health of unborn children is involved only injects an emotional element that re-enforces stereotypes of women as mothers; ${ }^{179}$ it adds nothing new to the legal equation because individuals have a constitutional right to decide questions relating to procreation. ${ }^{180}$ If the employee wishes to shoulder the risk of harm to herself or her child, that is no one's business but her own. ${ }^{181}$

These points, taken individually, are valid as far as they go. They do not, however, demonstrate satisfactorily that any employee has the right to assume the risk of fetal as well as personal injury. Women and men should certainly retain their right to assume the risks of dangerous or hazardous employment. But when fetal health is implicated, sex-based discrimination may well be excusable. Given the social and economic costs of producing and caring for defective children and the substantial likelihood that the employment of workers in unhealthful environments will result in the birth of such children, ${ }^{182}$ it is justifiable to exclude some members of one sex from a very narrow class of industries in order to prevent this outcome-as long as the exclusion is in fact narrowly tailored, objectively applied, and based upon credible scientific evidence.

Of course, as demonstrated earlier, ${ }^{183}$ the interest in fetal health does not fall within the class of business purposes currently recog-

${ }_{177}$ Such a duty, if it arises at all, would arise under the OSH Act, and not under title VII. But see notes 57-66 supra \& accompanying text.

178 See text accompanying notes $129-31$ \& note 131 supra.

179 In one author's words, the "perpetual pregnancy myth." J. STErrinaN, supra note 16, at 178 . (1972).

180 See Roe v. Wade, 410 U.S. 113 (1973); Eisenstadt v. Baird, 405 U.S. 438

181 See Colum. Note, supra note 15, at 133-35; Letter from Joan E. Bertin, Staff Counsel, American Civil Liberties Union Foundation, to the Environmental Protection Agency, Office of Pesticides and Toxic Substances, at 4 (Sept. 12, 1980).

182 See Furnish, supra note 15 , at $66 \&$ n.13.

183 See notes 132-35 and 156-58 supra \& accompanying text. 
nized by the courts as justifications for sex discrimination under title VII. The interest is, instead, a public interest in the healthy and normal development of an unborn fetus. ${ }^{184}$ It may be argued that the employer may not take on the mantle of the state in protecting the unborn child; ${ }^{185}$ and that, even assuming the employer's power to protect the fetus, the employee's right to his or her job overrides any interest in the fetus, at least until the point of viability.

Admittedly, neither of these arguments can lightly be dismissed. But when all the interests are placed in the balance-the employee's interest in a healthful work environment and equal employment opportunity, the state's interest in fetal health, and the employer's interest in maintaining a profitable enterprise-the answer becomes clear: the state should not compel the employer, through title VII, to hire women or men if the safety of their unborn cannot reasonably be assured.

Businesses should be encouraged to make socially responsible business decisions. The concept of corporate social responsibility, ${ }^{186}$ although not fully developed in the law, certainly has a place when the employer's only choices may be to exclude the worker, risk defective births, or close down his operation. In this situation, the employer's interest in avoiding the cost of liability-coupled with the very high social and human costs incurred when children are born defective-serves both his business and the public interest. ${ }^{187}$ Taken separately, none of these interests would suffice as a defense under title VII. Taken together, the merely legitimate business

184 In Roe v. Wade, 410 U.S. 113 (1973), the Supreme Court recognized the state's compelling interest in protecting fetal health, but only in the third trimester of pregnancy when the fetus is said to be viable. Id. I63. Before that point, the mother's right to privacy is paramount and the state may act only to preserve the mother's health. Id.

185 Roe v. Wade, 410 U.S. 113 (1973), defined the power of the state, not private parties, to restrict a woman's right to an abortion.

188 The subject of corporate social responsibility has engendered lively debate in recent years. See, e.g., Commitre for Economic DevelopMent, Social REsponsIBIITIES OF Bustness Corporations (1971); Soctal ResponsmintTy and the Busnness Predicament (J. McKie ed. 1974); Corpotate Social Responsibility: A Symposium, 30 Hastrngs L.J. 1247 (1979); Curzan \& Pelesh, Revitalizing Corporate Democracy: Control of Investment Managers' Voting on Social Responsibility Proxy Issues, 93 Harv. L. Rev. 670 (1980); Engel, An Approach to Corporate Social Responsibility, 32 Stan. L. Rev. I (1979); Mundheim, A Comment on the Social Responsibilities of Life Insurance Companies as Investors, 61 VA. L. REv. 1247 (1975).

187 In contrast, the employer's interest in avoiding the expenses required to clean up the workplace-though admittedly a business purpose related to profitability-is not accompanied by the social and human costs of defective births. Thus, unlike avoiding the cost of liability, avoiding the cost of clean-up (or other safety measures) is not an interest sufficiently overriding to justify an exclusionary policy. 
purpose, accompanied by compelling public interests, should succeed in making out the claim of an overriding interest necessary to justify an exclusionary policy under title VII. ${ }^{188}$

The ability of the employer to justify exclusion by asserting both business and public interests does not, of course, end the inquiry. The mother's rights, both statutory and constitutional, must also be considered. Clearly, the mother's statutory right to nondiscriminatory employment decisions-like her constitutional right to privacy-is not absolute. ${ }^{189}$ At some point, her interests can be subordinate to the important public interest in the healthy and normal development of an unborn fetus. ${ }^{190}$ A similar analysis applies to males whose offspring would be damaged by parental exposure to hazardous chemicals. In either case, a distinction can and should be drawn between the individual's right to terminate a pregnancy or make other decisions relating to reproduction and the right knowingly to risk a defective birth while subjecting a third party to liability for the defects.

Thus, there are indeed situations in which a discriminatory employment practice may be justified by risk of harm to the unborn. The next task is to determine in what circumstances this may be true, and craft a legal standard that will yield the correct result.

\section{Beyond Title VII and OSHA: A Proposal FOR CHANGE}

\section{A. General Considerations}

An analysis of the pertinent public policy issues leads to the reluctant conclusion that sex-based discrimination in employment

188 This view is consistent with the reasoning in Spurlock v. United Air Lines, 475 F.2d 216 (10th Cir. 1972), in which very high social and human costs raised a merely legitimate business purpose to the level of an overriding legitimate purpose. Generally, the federal courts have been more receptive to employer defenses based upon the health and safety of third parties, see New York City Transit Auth. v. Beazer, 440 U.S. 568, 587 n.31 (1979); Worthy v. United States Steel Corp., 616 F.2d 698, 701 (3d Cir. 1980); Spurlock, 475 F.2d at 219, than to defenses based upon a threat to the safety or health of the employee herself. See text accompanying notes $129-31$ supra. Courts may be equally solicitous of fetal health.

Admittedly, in the cases discussed above, the class of persons that the employer has been permitted to protect consists primarily of consumers of the employer's product, see, e.g., Beazer, 440 U.S. 568 (1979) (subway riders); Harriss v. Pan Am. World Airways, Inc., 24 Empl. Prac. Dec. $\llbracket 31,425$ (9th Cir. 1980) (airline passengers); Spurlock, 475 F.2d 216 (10th Cir. 1972) (airline passengers). Protecting such a class is consistent with an employer's business interest, as that term is narrowly defined. Nonetheless, at least one court has talked in terms of protection of the "general public." Worthy, 616 F.2d at 701 (dictum).

189 Roe v. Wade, 410 U.S. 113 (1973).

190 Id. 163. 
may in some circumstances be justified by the possibility of workplace harm to the unborn. It is clear, however, that current title VII law does not allow for such discrimination in any circumstances. The next task of this Article is to propose changes in the current state of sex discrimination law that will fairly balance the competing interests involved.

A review of the relevant legislation suggests how these various interests should be weighted. The enactment of the Occupational Safety and Health Act of $1970^{191}$ reflects the judgment of the Congress that the marketplace does not adequately and equitably distribute the risks to worker safety and health. Similarly, the passage of title VII ${ }^{192}$ demonstrates that Congress believed that prevailing market forces would not eliminate discrimination in employment. Further, both acts establish the expense of eliminating discrimination and the maintenance of a healthful work environment as costs of doing business. Therefore-consistent with the spirit both of title VII and the OSH Act ${ }^{193}$-the proposal outlined here emphasizes that the worker's interests in a safe and nondiscriminatory employment are matters of public policy and, as such, weigh more heavily in the balance than the employer's private interest in business profitability.

Thus, although the major policy judgment required here balances the worker's interest in nondiscriminatory employment decisions against the unborn child's healthy development, the practical conflict is between worker safety and the employer's business profitability. The proposal offered here provides a compromise that favors both parties. Relying upon judicial modification of the judicially created manifest business necessity defense, the proposal expands the defense to recognize a compelling business purpose in the avoidance of a substantial risk of prenatal injury to the worker's unborn child-a defense to the title VII claim that presently does not exist. The proposal also limits the applicability of the manifest business necessity defense in the case of fetally toxic work environments to cases in which the employer cannot protect the unborn child through methods other than the exclusion of susceptible workers.

Two factors complicate the development of a sound legal scheme. The first is primarily practical and concerns the possibility

191 Pub. L. No. 91-596, 84 Stat. 1590 (codified at 29 U.S.C. $\$ \$ 651-678$ (1976, Supp. II 1978 \& Supp. III 1979)).

192 Pub. I. No. $88-352,78$ Stat. 253 (codified at 42 U.S.C. $\$ \$ 2000$ - to 2000e-17 (1976 \& Supp. III 1979)).

$193 \mathrm{Cf}$. 3 J. Sutherrañd, Statutes aNd Statutory Construction $\$ 60.01$ (4th ed. C. Sands 1974) (remedial statutes should be broadly construed to effectuate their beneficent statutory purpose). 
of jurisdictional conflicts between the federal courts and the Occupational Safety and Health Review Commission (OSHRC). ${ }^{194}$ The federal courts are presumably not as competent as OSHRC to make determinations concerning workplace safety, which involve complex factual and policy judgments requiring a high degree of scientific expertise and familiarity with the realities of the workplace. ${ }^{195}$ Similarly, the corps of administrative law judges that administers the OSH Act has no jurisdiction respecting and is not necessarily competent to pass judgment on questions of discrimination and title VII law ${ }^{196}$-generally the bailiwick of the federal courts. ${ }^{197}$ Any proposed scheme must take into account these difficult problems of variant jurisdiction and expertise.

Further complicating the development of a workable legal scheme is the emotional nature of the problem, which involves questions of maternal health and pregnancy. Society remains burdened with many sexual myths concerning the fragility of the female relative to the male, her propensity and desire to become pregnant, and her inability to make rational decisions concerning her own wellbeing. ${ }^{198}$ Saddled with these stereotypes, it will take an extraordinary effort by any federal judge to achieve the degree of judicial impartiality necessary for a principled and just decision.

\section{B. A Modest Proposal \\ 1. The "Easy" Cases}

There are two cases in which the problem of sex-based discrimination to protect the health of the employee or his or her unborn is readily resolvable under existing legal doctrines. First, consider the case of disparate treatment, in which the employer specifically and overtly excludes or discriminates against one sex or a subclass thereof. Such overt discrimination is not justifiable under existing title VII law, ${ }^{199}$ and there is no reason why existing law should be

194 See text accompanying note 55 supra.

195 See Marshall v. Cities Service Oil Co., 577 F.2d 126, 130 (10th Cir. 1978); Brennan v. OSHRC, 501 F.2d 1196, 1198-99 (7th Cir. 1974), Cf. 29 U.S.C. $\$ 660$ (a) (1976) (OSHA findings of fact, "if supported by substantial evidence on the record considered as a whole, shall be conclusive").

196 For example, the administrative law judge who heard the first OSHA complaint involving sexual discrimination in the workplace justified by disparately hazardous working conditions, see Secretary of Labor v. American Cyanamid Co., OSHRC Docket No. 79-5762 (July 15, 1980), demonstrated a marked reluctance to entangle himself in the discrimination question. See id. 8-11; note 57 supra.

197 See 42 U.S.C. $\$ 2000 \mathrm{e}-5(f)(3)(1976)$.

198 See notes 172-75 supra \& accompanying text.

199 See notes 87-105 supra \& accompanying text. 
altered. Even when the exclusion of some workers is necessary to protect their health, an employer should be required to adopt a gender-neutral practice or policy. Thus, while an employer could never tell a female applicant that he never hires women who are capable of bearing children, he may be able lawfully to exclude all individuals whose progeny would be seriously harmed by exposure to the hazardous workplace. ${ }^{200}$

The second "easy" case arises when the employer discriminates to protect workers from a workplace hazard that should, in compliance with the OSH Act, be eliminated or reduced. Obviously, an employer should not be permitted to use a violation of the law as a rationale for prima facie illegal discrimination. He should be required to comply with his duties under the OSH Act, in which instance the purported justification for exclusion no longer exists.

This "easy" case is more readily stated in theory than implemented in practice. Optimally, such a case would begin with an employee-discriminatee's complaint with the Department of Labor alleging the violation of an OSH Act duty. ${ }^{201}$ The complaint would result in an inspection of the employer's premises and a citation for violation of a specific regulation or the general duty clause. The citation might be contested before OSHRC and eventually litigated before a federal appellate court. ${ }^{202}$

If the citation survives judicial or quasi-judicial scrutiny, the discriminatee could use any relevant final determination against the employer in a subsequent title VII suit. Preferably, the determination would have collateral estoppel effect. ${ }^{203}$ If so, summary dis-

200 Cf. Guidelines, supra note 9 , at $\$ 2(a)$.

Admittedly, such a bright line distinction between disparate impact and disparate treatment cases seems somewhat artificial in the current context. Although a policy having a disparate impact on women workers may be cast in neutral terms, it is highly likely that the employer will be fully aware of the disparate effect. Nonetheless, the distinction exists in the current law, and is defensible as a policy matter. A facially neutral policy is not as insulting and apparently arbitrary to the discriminatee class as an overtly discriminatory one. Furthermore, if an employer in good faith attempts to formulate a neutral policy, he will be forced to carefully consider and define those classes of individuals that may justifiably be excluded. This may in turn lead to less unjustifiable discrimination. 201 See note 66 supra \& accompanying text.

202 Of course, OSHRC has neither the competence nor jurisdiction to determine the merits of the discrimination component of the employee's claim. See note 57 supra.

203 The doctrine of collateral estoppel has been extended to the decisions of administrative agencies in appropriate cases. United States v. Utah Constr. \& Mining Co., 384 U.S. 394, 422 (1966). See Note, The Collateral Estoppel Effect of Administrative Agency Actions in Federal Civil Litigation, 46 Geo. Wash. L. REv. 65 (1977). The Seventh Circuit has stated that "issue preclusion applies to a final administrative determination of an issue properly before an agency acting in a judicial capacity when both parties were aware of the possible significance of 
position of the title VII question would be the likely result, as in most cases the discriminatory impact of the employer's policy will be lightly contested. If not, the OSHA-level disposition could be given whatever evidentiary weight that the fact finder deemed it merited.204

A different case arises when an aggrieved employee or applicant sues in federal court under title VII without the benefit of an OSHRG disposition, but nonetheless alleges that the employer is in violation of his duties under the OSH Act. A resolution of the $\mathrm{OSH}$ Act question is tempting even without specific guidance from OSHA, as this will as a practical matter often decide the case. But an argument can be made that a federal court is without jurisdiction to decide an issue of worker health not passed upon by OSHA. After all, OSHRG is vested with nearly exclusive original jurisdiction to compel compliance with its standards. ${ }^{205}$ In addition, OSHRC has the expertise to make rational and consistent determinations on issues of employee safety and health. ${ }^{206}$

This argument, though not without merit, can be carried too far. Just as OSHA bears primary responsibility for deciding questions of workplace health and safety, federal courts bear the burden of resolving problems of discrimination under title VII. ${ }^{207}$ Merely

the issue in later proceedings and were afforded a fair opportunity to litigate the issue and to obtain judicial review." Bowen v. United States, 570 F.2d 1311, 1322 (7th Cir. 1978) (footnote omitted). Under this test, it would appear reasonable to permit a plaintiff to make offensive use in a title VII suit of a determination by OSHRC that an employer was in violation of the OSH Act. See Parklane Hosiery Co. v. Shore, 439 U.S. 322 (I979).

204 Cf. Arthur v. Flota Mercante Gran Centro Americana S.A., 487 F.2d 561, 564 (5th Cir. 1973) (violation of safety and health regulations is negligence per se in some circumstances); Buhler v. Marriott Hotels, Inc., 390 F. Supp. 999,1000 (E.D. La. 1974) (evidence that OSHA standards have been violated admissible to prove negligence). See also Guidelines, supra note 9 , at $\S 2$ (d)(2) (making employer compliance with the OSH Act a relevant factor in determining whether an effectively sex-based discriminatory practice is justified); $i d$. at $\$ 2$ (d)(8)(iv) (establishing a presumption that an employer who is not in compliance with the OSH Act has not considered all available alternatives to a policy that effectively discriminates on the basis of sex).

20529 U.S.C. $\$ 659$ (c) (1976) (granting the employer the right to a hearing before OSHRC to contest a citation). OSHRC determinations are, of course, reviewable in the federal circuit courts. See 29 U.S.C. $\$ 660$ (1976). Furthermore, the federal district courts may entertain actions for injunctive relief brought by the Secretary of Labor (or, if the Secretary arbitrarily refuses to seek such relief, by any employee at risk) to correct practices or procedures posing an imminent and substantial danger of serious physical harm to employees. 29 U.S.C. $\$ 662(\mathrm{a})$ \& (d) (1976).

208 See note 195 supra \& accompanying text.

207 In fact, OSHRC may have no jurisdiction whatsoever to decide discrimination-related issues. See note 57 supra. 
because a question of employee health is bound up with a claim of employment discrimination does not mean that the courts should abdicate all responsibility for deciding the title VII claim. Rather, the issue requires some standard by which the courts can evaluate the employer's worker safety justification without usurping OSHA's jurisdiction or moving too far beyond the courts' expertise.

Certainly, there will be some cases in which the scientific evidence is so clear that no particular expertise or industrial experience is necessary to determine whether the employer can or should reduce the risk to worker safety or health. In such cases, the primary reason for deferring to OSHA would not exist. If a court can affirmatively and comfortably hold that an employer is "clearly avoiding" a duty imposed upon him by the OSH Act, then there is no reason why the court should not do so. ${ }^{208}$ In those cases in which the evidence on the issues is not so clear, or an OSHA proceeding is in process, the court may exercise its discretion to delay the title VII proceeding until the plaintiff seeks or obtains redress through OSHA. Otherwise, there is no reason why a title VII claimant should have to wait for OSHA's involved administrative machinery to turn before seeking vindication of his or her title VII rights. ${ }^{208}$

\section{The "Harder" Case}

A harder case arises when an employer seeks to justify otherwise invidious discrimination by reference to a workplace hazard from which he is under no clear OSH Act duty to protect his employees. Such a case would most likely arise when the toxic effects of a widely used or newly introduced chemical are just coming to light, or alternatively, when OSHA has not addressed a specific hazard. In such circumstances either no OSHA standard will

208 Fact finders in common law negligence cases have been permitted to determine whether or not an OSH Act duty has been breached. See, e.g., Knight v. Burns, Kirkley \& Williams Const. Co., 331 So. 2d 651, 654 (Ala. 1976); Disabatino Bros. v. Baio, 366 A.2d 508, 510-11 (Del. 1976).

200 The obvious procedural difficulties outlined here highlight the fact that private title VII litigation cannot provide the necessary systematic approach to the problem of reproductive hazards in the workplace. Ultimately, the EEOC and OSHA-perhaps in conjunction with the Office of Federal Contract Compliance Programs (OFCCP), which can recommend the withholding of government contracts for violations of federal employment standards, see Exec. Order No. 11,246, $\$ 209$ (a), 3 C.F.R. 339 (1964-1965 Compilation), reprinted in 42 U.S.C. $\$ 2000$, at 1234 (1976) - should develop a schedule by which the government institutes an industry-by-industry challenge of the practice of excluding fertile women. Although the process would be slow, the primary advantage of such a scheme would be to allow government charges of discrimination to track OSHA's development of data and standards for each toxic substance. 
apply ${ }^{210}$ or the chemical health hazard is not likely to be "recognized" under the OSH Act's general duty clause.211

The court will be unable to make short shrift of the employer's defense by pointing to a clear breach of duty under the OSH Act. In fact, neither OSHA nor OSHRC can play a direct role here because there is no breach of the Act. Nonetheless, the court faces a claim of discrimination, and must resolve it. Without a clear policy directive from OSHA, the court's disposition of the discrimination claim must be tied to title VII alone. Analogies may be drawn and concepts borrowed, but that is the extent of OSHA's. relevance.

Of course, the "harder" case becomes relatively easy if the plaintiff can prove pretext..212 For example, the plaintiff may demonstrate the existence of a health risk to the opposite sex as substantial as that to the plaintiff's sex, which the employer has done nothing about. ${ }^{213}$ Certainly it would be suspicious that the employer's supposed beneficence is selectively applied "in favor" of the discriminatee's sex. More difficult to prove, but equally effective as a showing of pretext, would be the fact that the employer has protected the unexcluded sex from a similarly substantial risk by means less drastic than the means advanced (and perhaps rejected as unavailable) in the case at bar. Either way, an inference arises that the employer is motivated against the adversely affected sex, or at least, recklessly or unreasonably disregards a substantial risk of harm to the other sex. In either case, the sexes are being subjected to unequal treatment, and the plaintiff makes out a case of pretext.

210 See notes 58-59 supra \& accompanying text.

211 See notes 50-51 supra \& accompanying text.

212 Pretext is usually thought of in terms of a disparate treatment analysis. See text accompanying note 75 supra. However, it has a place in disparate impact analysis as well. See, e.g., Burwell v. Eastern Air Lines, Inc., 633 F.2d 361, 372 \& n.18 (4th Cir. 1980) (per curiam), cert. denied, 49 U.S.L.W. 3643 (U.S. Mar. 3, 1981) (Nos. 80-868 \& 80-1076). The notion of pretext serves as a bridge linking the two legal theories-if the plaintiff in a disparate impact case proves pretext, she or he has really transformed the case back into the disparate treatment mold.

213 A major flaw of the proposed and withdrawn guidelines, see note 9 supra, is their limited attention to the problem of pretext. The guidelines focus exclusively on the employer's policies respecting the relative risks of "reproductive hazards" faced by the excluded and the unexcluded workers and not on other health hazards. By contrast, the proposal offered here does not distinguish between reproductive hazards and other health hazards of the workplace. The proposal focuses, rather, on the employer's treatment of all workplace hazards. For example, an employer's entire workforce may face a significant risk of cancer, while fertile women face the only risk of significant reproductive injury. The employer could not, under the proposal, justify a discriminatory policy by claiming that a risk of reproductive injury cannot be tolerated, while the cancer risk remains. 
The difficulties inherent in the "harder" case arise when the plaintiff is unable to prove pretext. Current title VII law is simply not adequate to resolve such cases. As presently interpreted, title VII flatly forbids exclusion-even if there is no showing of pretext and the toxic chemical is shown to be extremely hazardous to the employee's unborn children. Thus, it is proposed that after the employee has proved a prima facie case of impact discrimination, the employer may justify the discriminatory practice by proving that, but for the discrimination, the health of the employee's unborn children would be substantially and unreasonably at risk, and that no less discriminatory alternatives are available to reduce the risk to acceptable levels. ${ }^{214}$

The first point to emphasize concerns the nature of the risk. It must be so "substantial" as to exceed a threshold degree of harm. Thus, injury must result in permanent or serious temporary impairment that affects normal functioning. The risk must also be "unreasonable" such that the interests of the worker in being gainfully employed and free from discrimination do not outweigh the social interest in maintaining the health of the worker's unborn child. If the risk is neither substantial nor unreasonable, the employer would not be permitted to exclude.

A word must be said concerning the nature of the evidence needed for an employer to prove the substantiality and unreasonableness of a workplace risk. Such evidence will be the product of scientific research. As a body of facts from which rational inferences may be drawn, scientific research is fraught with dangers.215 Thus, the court should be particularly demanding in evaluating the admissibility and use of such evidence. Admittedly, scientific evidence of long-term hazardous effects is rarely a certain predictor. ${ }^{216}$ Nonetheless, the evidence must give rise to a clear inference that the alleged harm predicted is likely to arise with the alleged frequency and within the allegedly endangered worker population.

214 This is not to imply that the employer would no longer have available to him the usual manifest business necessity defense. See text accompanying notes 144-48 supra. Thus, if a workplace hazard directly affected the physical capacity of one sex to perform the job but did not adversely affect the other sex, a discriminatory practice affecting only one sex may be justifiable.

215 See notes $42-43$ supra \& accompanying text.

216 Cf. NAACP v. Wilmington Medical Center, Inc., 491 F. Supp. 290, 293 (D. Del. 1980) (court, upon being asked to predict the impact on the delivery of health-care service to minority groups caused by the future relocation of a major urban medical center, termed itself "unwillingly cast ... into the role of a modern day Nostradamus"). 
The evidence must also be "reputable." ${ }^{217}$ Not only must the court be satisfied that the research methodology is sound, but also that it is untainted by conscious or unconscious sexual bias. Thus, a study of the hazardous effects of a substance involving the members of only one sex would be accorded very little weight. 218 Indeed, the slight probative value of such evidence would render the evidence inadmissible on the factual issue whether members of one sex are subject to a health risk that differentiates them from other workers. ${ }^{219}$

The employer who proves the existence of a real and substantial health threat must still rebut any claim by the plaintiff that less discriminatory alternatives exist to serve the interest in worker safety. Such other available alternatives would include cleaning up the workplace or otherwise protecting the endangered employees.

Although cleaning up the workplace may be an undertaking qualitatively different from the remedies and employer requirements usually associated with title VII, it is not conceptually out of bounds with title VII law.220 Title VII defendants have been ordered to revamp entirely their job testing and training procedures in order to eliminate racial impact discrimination. ${ }^{221}$ Municipalities have been required to make major changes in their transportation systems ${ }^{222}$ in order to comply with the Rehabilitation Act of $1973,{ }^{223}$ a statute in many ways analogous to title VII.224 Nor does

217 Cf. Guidelines, supra note 9 , at $\$ 2(\mathrm{~d})(3)$ (requiring the employer to present "reputable" scientific evidence to justify a discriminatory employment practice). The guidelines do not define the term "reputable" but do require scientific research undertaken by the employer in order to support a temporary exclusion to be conducted "according to accepted scientific methods." Id. $\S 3(b)(2)$.

218 See note 42 supra \& accompanying text. Cf. Guidelines, supra note 9, at $\$ \S 2(d)(3), 3(b)(2)$ (requiring employer investigation and research into the effects of any reproductive hazard on the non-excluded sex).

219 But see Doerr v. B.F. Goodrich Co., 484 F. Supp. 320,326 n.4 (N.D. Ohio 1979), in which the court seemed prepared to permit justification of a sexbased exclusionary policy on the basis of an incomplete scientific record. If such evidence were instead inadmissible, and "reputable," balanced scientific research were required, employers may be motivated to do or cause to be done thorough and unbiased research-a worthwhile by-product of the strict evidentiary standard.

220 See Franks v. Bowman Transp. Co., 424 U.S. 747, 762-64 (1976).

221 E.g., United States v. County of Fairfax, 629 F.2d 932, 942 n.11 (4th Cir. 1980) (personnel record keeping); Vulcan Soc'y v. Civil Serv. Comm'n, 490 F.2d 387, 395-98 (2d Cir. 1973) (employment tests); United States v. Georgia Power Co., 474 F.2d 906, 925-26 (5th Cir. 1973) (hiring practices); 29 C.F.R. $\$ 1607$ (1980) (Uniform Guidelines on Employee Selection Procedures).

222 See Leary v. Crapsey, 566 F.2d 863 (2d Cir. 1977); Lloyd v. Regional Transp. Auth., 548 F.2d 1277 (7th Cir. 1977); Bartels v. Biernat, 427 F. Supp. 226 (E.D. Wis. 1977).

22329 U.S.C. $\$ \$ 701-796 i$ (1976 \& Supp. III 1979).

224 The portions of the Rehabilitation Act and its associated regulations dealing with discrimination look in many ways like a codification of title VII common law 
the existence of the OSH Act indicate otherwise. There is nothing in the $\mathrm{OSH}$ Act to suggest that it preempts the field of occupational safety and health from the reach of other federal statutes. ${ }^{225}$ In short, there is no conceptual reason why an employer could not be required under title VII to eliminate a health risk in the workplace.

Of course, the employer might have a colorable defense here if the clean-up measures would be very expensive. Although no court has articulated a precise standard for determining when cost becomes prohibitive, at some point cost will render the proposed alternative "unavailable" to the employer. The question is where that line should be drawn.

The measure of the availability of an appropriate alternative falls somewhere between de minimis cost and prohibitive cost. Clearly, it is unreasonable to burden the employer with an alternative policy that all but bankrupts his business. Imposition of such a burden would not only ignore the employer's legitimate interest in business profitability, but would also force him to forego the elimination of other health risks in the workplace and the demands of corporate social responsibility in other areas. ${ }^{226}$

It is appropriate, however, to require the employer to investigate and to adopt protective measures that, while not unduly burdensome, do impose substantial costs or other burdens on the business. After all, the public policy objectives served here-

as it would apply to handicapped persons. Discrimination against "qualified handicapped individuals" in all private and public programs receiving federal financial assistance is forbidden. Id. $\$ 794$. Federal contractors may be required to take affirmative action to employ and to promote "qualified handicapped individuals." Id. \$793.

Handicapped individuals may not be excluded from employment or from a covered program if capable of performing the "essential functions" of the job with "reasonable accommodation." 45 C.F.R. \$84.3(k)(I) (1980). "Reasonable accommodation may include: (1) making facilities used by employees readily accessible to and usabe [sic] by handicapped persons, and (2) job restructuring, part-time or modified work schedules, acquisition or modification of equipment or devices, the provision of readers or interpreters, and other similar actions." Id. $\$ 84.12$ (b). Employment selection criteria must be "job-related," and the employer, in order to exclude a handicapped person, must demonstrate that the handicap impedes the worker's present ability to perform the job. Id. $\$ \$ 84.13$, 84.14. Financial costs and expenses associated with accommodation may permit the employer to forego his duties under the Act only if they create "undue hardship" for that individual employer. See id. $\$ \$ 84.12(\mathrm{a}),(\mathrm{c}), 84$ app. A. subpt. B. at $357-58$.

225 On the contrary, the OSH Act does not "apply to working conditions of employees with respect to which other Federal agencies ... exercise statutory authority to prescribe or enforce standards or regulations affecting occupational safety or health." 29 U.S.C. $\$ 653($ b)(1) (1976). See generally Comment, Interpreting OSHA's Pre-emption Clause: Farmworkers as a Case Study, 128 U. PA. L. REv. 1509 (1980).

226 See note 186 supra \& accompanying text. 
elimination of both discrimination and the risk of fetal harm-are highly regarded. Congress and the courts have mandated that the expense of eliminating discrimination from employment is a cost of doing business and that the employer cannot expect his duties under title VII to be cost-free. ${ }^{227}$ Similarly, Congress has imposed upon employers the often substantial costs of compliance with the OSH Act. ${ }^{228}$ Thus, in the case at hand, an alternative employment policy should be considered "available" if the cost of the alternative policy will not create an undue financial hardship for the employer and if the necessary technology is within the employer's reach or can be readily developed.

The "unduly burdensome" standard is admittedly vague, and neither Congress nor the courts has articulated any more precise parameters. Some guidance may be found in the test validation cases, in which employers have been required to bear the substantial cost of validating and implementing new employment tests. ${ }^{229}$ Analogies can also be drawn to the Rehabilitation Act, ${ }^{230}$ which requires compliance unless the employer can demonstrate "undue hardship." 231 In both areas, employers have been expected to bear far more than merely incidental costs. The upper limit of their potential burden, however, has not been established. That task can only be accomplished on a case-by-case basis in the courts.

If the court finds that the employer could obviate the need for a discriminatory practice by reducing or eliminating the hazard, the employer's defense fails, and the court should order not only an end to the exclusionary practice, but also prompt implementation of the less discriminatory measures. Only if no less discriminatory alternatives exist-and only if the evidence has clearly and convincingly established that any other policy would expose the unborn children of members of one sex to a substantial and unreasonable risk of harm-can the exclusionary policy stand. Even then, the court may stipulate that the employer undertake additional research or develop new technology, which in time might eliminate the need for the discriminatory policy.

One intimidating problem still looms. Any such discriminatory employer policy would, of course, have to be narrowly tailored to disadvantage only those individuals who were subject to the

227 See Robinson v. Lorillard Corp., 444 F.2d 791, 799-800 (4th Cir.), cert. dismissed, 404 U.S. 1006 (1971).

228 See note 47 supra.

229 See note 221 supra \& accompanying text.

230 See notes 222-24 supra \& accompanying text.

231 See note 224 supra \& accompanying text. 
health risk. Thus, a narrowly and properly tailored exclusion would not affect workers who are infertile whether naturally or by reason of surgical sterilization. The very difficult issue is whether an employee or applicant should be able to remove herself or himself from the class of excludable workers by submitting to a voluntary surgical sterilization. ${ }^{232}$

It is arguable that the decision whether to lose the job or to be sterilized should be left to the individual worker. An equally compelling argument can be made that the employer should not be allowed by the court to impose sterilization as a condition for employment.

Frankly, neither choice is satisfactory. It would be most unfortunate if new research or technology made such "voluntary" operations unnecessary after workers had submitted to them. And public policy dictates that such drastic measures not be required in exchange for a weekly paycheck. In practical terms, however, it would be virtually impossible for the employer to distinguish those applicants who were sterilized in order to get the job from those who were sterilized for any other reason. Even if this practical difficulty could be solved, the more pressing legal and ethical problems remain. On balance, the spirit of title VII-maximization of worker choice-leads to the uncomfortable conclusion that the decision be left to the individual employee.

\section{The "Hardest" Case}

The hardest case arises when OSHA has affirmatively decided that the employer is in compliance with the OSH Act even though there exists in the workplace a toxin that is dangerous to fetal health. It is arguable that for a court to require the employer to take protective measures would mean that the court was secondguessing OSHA.

Compliance with the OSH Act, however, is not necessarily a defense to a title VII claim. Although they appear similar, the worker safety issues in the OSHA proceeding and in the title VII litigation are substantively different issues.

The first obvious difference is that OSHRC may dismiss an OSHA citation for technical reasons, such as statutory time limitations, ${ }^{233}$ which have no bearing on the existence of a workplace

232 For a discussion of the American Cyanamid case, in which such sterilization actually occurred, see notes 241-54 infra \& accompanying text; note 11 supra.

233 "No citation may be issued ... after the expiration of six months following the occurrence of any violation." 29 U.S.C. $\$ 658(\mathrm{c})(1976)$. 
hazard. ${ }^{234}$ The second obvious difference is that OSHA applies an industry-wide standard when determining the required degree of safety within the workplace, ${ }^{235}$ while title VII inquires whether the individual employer can achieve his purpose of worker safety through means other than the challenged discriminatory practice.

Even though there may be no violation of the OSH Act, title VII requires the employer to adopt and implement available alternative practices if he can thus avoid disadvantaging a disproportionate number of workers of one sex. The availability of an alternative, less discriminatory policy remains a factual issue in the title VII litigation even though the employer is not in violation of the OSH Act. When the title VII defendant is an atypical employer within an industry, he may have a greater financial or technological capacity to reduce the health risks to his employees than has the average employer within the same industry. Title VII may require such an employer to implement safety measures that the $\mathrm{OSH}$ Act does not require.

The third, less obvious, difference is that OSHA is required to include a cost-benefit analysis in its formulation of exposure levels and other measures of worker safety. ${ }^{236}$ Title VII imposes no similar affirmative duty upon the court. Further, reduction of the risk to fetal health is but a secondary goal of title VII in the present case. The primary goal is to reduce the discriminatory impact of the challenged practice. Title VII may well require the employer to take additional measures to preserve the employment rights of the otherwise excluded workers. These may range from temporary medical removals of longer duration than is required under an OSHA standard to permanent reassignment of at-risk employees or more sophisticated safety technologies.

Finally, the findings of an earlier judicial proceeding will not have collateral estoppel effect against a party to a subsequent proceeding who was not a party to the earlier proceeding. ${ }^{237}$ Unlike the OSHA proceeding, the title VII litigation involves a private action by a plaintiff whose personal interest in back pay, reinstatement, or other equitable remedies may cause a more rigorous or differently focused litigation of the relevant factual issues. The defendant employer may not, therefore, estop the plaintiff from

234 But see M. RotristeIN, supra note 44 , at $\$ 400$ ("[T] Commission has maintained the policy that cases should be heard on the merits and should not be decided on threshold procedural issues.").

235 See note 47 supra.

$238 \mathrm{Id}$.

237 See Restatement (Second) of Judgments $\$ 68$ (Tent. Draft No. 1, 1973). 
litigating the factual issues regarding worker health and available alternative practices on the basis of the results of an earlier administrative proceeding to which the plaintiff was not a party, however relevant the earlier findings.

Certainly, if the OSHA disposition resulted from a finding that health risks in the employer's workplace are insufficient to trigger an OSH Act duty, the court should be made aware that the employer's assertion that a substantial risk justifies a discriminatory policy contradicts his position in the earlier proceeding. In that case, the OSHA finding and the employer's arguments in support thereof could be introduced by the plaintiff against the employer to establish that the risk asserted by the employer as a title VII justification is insubstantial or does not exist. Such contradictory factual claims would be good evidence that the policy is a pretext for sex discrimination.

Thus, an affirmative decision by OSHA that the employer is in compliance with OSHA duties should not determine the outcome under title VII. As in any other case in which an earlier proceeding may have resolved the same issues, the court should review the OSHRC findings to determine whether the same factual issues formed the basis of the OSHA findings as are at issue in the title VII litigation. If the factual issues are the same, the court should give them the proper evidentiary weight, but not a collateral estoppel effect. Of course, the OSHA findings will have greater weight on the issue of the availability of less discriminatory alternative practices and relatively little weight on the question whether the business purpose of protecting the workers from the particular health risk outweighs the discriminatory impact of the challenged exclusionary practice.

\section{The Proposal Applied}

OSHA and EEOC consideration of the risks associated with lead highlight the practical and theoretical problems posed by the search for a way to protect the unborn from the hazards of workplace exposure to toxins. OSHA standards for occupational exposure to lead specifically take into account the effects of the prenatal and preconception exposure of the worker on a subsequently born child. ${ }^{238}$ In its findings respecting the lead workplace, OSHA stated that reproductive injury in male and female lead workers can affect the worker's ability to conceive a normal child or to

23828 C.F.R. $\$ 1910.1025$ (j)(3)(c) (1980); id. app. A. 
conceive at all.239 The OSHA lead standards were challenged by the industry in federal court and have been upheld, in substantial and pertinent part, by the District of Columbia Circuit Court of Appeals. ${ }^{240}$

In a separate proceeding, OSHA issued a citation against the American Cyanamid Company, alleging that the company's establishment of surgical sterilization as a condition of employment violated the OSH Act. ${ }^{241}$ OSHRC dismissed the citation. ${ }^{242}$ Citations brought against the employer in a separate action, which directly related to the then existing lead standards, were upheld in part. $^{243}$ At the same time, many of the affected women employees of American Cyanamid filed charges with the EEOC alleging sex discrimination, and eventually filed suit in the federal court. ${ }^{244}$

The complaint alleges that American Cyanamid's fetal protection policy violates title VII because it places a condition of employment upon otherwise fertile women-sterilization-that it does not impose upon men. ${ }^{245}$ Under the proposal presented herein, the court could easily dispose of the claim by finding that the practice constitutes impermissible sex-plus discrimination. ${ }^{246}$ Even given due allowance for an employer's legitimate interest in fetal health, there is no reason to tolerate such overt disparate treatment.

The case as presented, however, primarily represents a drafting problem for the employer. There is no reason why American Cyanamid or any other company in a similar position could not formulate an exclusionary policy in sex-neutral terms, and then apply the policy in a manner as to impact women only. In that

239 Id. app. A.

240 United Steelworkers v. Marshall, No. 79-1046 (D.C. Cir. Aug. 15, 1980).

241 Secretary of Labor v. American Cyanamid Co., OSHRC Docket No. 79-5762 (July 15, 1980). The employer's so-called "fetus protection policy" precluded the employment of any women of presumed childbearing capacity in certain manufacturing positions involving exposure to lead compounds. A female under age fifty was presumed to be fertile. This presumption could be rebutted by proof of sterilization. Id. 4-5.

242 Id. The administrative law judge (ALJ) gave three reasons for dismissing the citation. First, none of the sterilizations had occurred within the OSH Act's statute of limitations period. Id. 6-7. Second, plaintiff's legal theory-that sterilization constituted an impermissible "condition of employment," which violated OSHA's general duty clause-was rejected as a misreading of the OSH Act. Id. 8. Last, the ALJ held that the OSH Act was preempted by title VII on these facts. Id. II.

243 Secretary of Labor v. American Cyanamid Co., OSHRC Docket No. 79-2438 (Aug. 20, 1980).

244 Christman v. American Cyanamid Co., No. 80-0024-P (N.D. W. Va., filed May 20, 1980).

$245 \mathrm{Id}$.

246 See notes 99-100 supra \& accompanying text. 
case, the policy survives the charge of disparate treatment on its face but nonetheless, on the record, falls on the ground of pretext. The recently upheld OSHA lead standards state that lead poses a threat to the unborn child of both male and female workers. ${ }^{247}$ If the court chose to accept this administrative determination, or, alternatively, if it reached a similar conclusion on its own after review of the reputable scientific evidence, then the court could find that the employer intentionally discriminated because he excluded only females when the threat to the unborn of male employees was substantially similar. Furthermore, this particular employer, American Cyanamid, had been found in violation of the OSH Act by an OSHRC administrative law judge. Unless and until the employer is in full compliance with the OSH Act, a presumption of pretext should arise. Under a pretext analysis, the employer's policy clearly falls and the plaintiffs are entitled to relief.

There is, however, the possibility that American Cyanamid could lower the level of lead in the workplace environment ${ }^{248}$ to a point at which the substance no longer posed a substantial gametotoxic or mutagenic danger, but, acting as a teratogen, only threat.ened the fetus. ${ }^{240}$ In this case, the fetus is at risk only through the mother, and thus the pretext argument put forth above does not suffice to invalidate the employer's policy. ${ }^{250}$

Of course, there may be other evidence of pretext. If, for example, the court finds that the risks to employees of other injury from lead such as kidney disease and respiratory or cardiovascular impairment ${ }^{251}$ are also substantial, then the employer's concern for fetal health is clearly pretextual. This is unlikely to be the case, if, by the terms of the hypothetical, the lead exposure level is reduced below the point at which it poses a material mutagenic or gametotoxic danger.

In this case, assuming that the danger to fetal health is substantial, the employer policy survives unless less discriminatory alternatives to wholesale exclusion are shown to exist. One that immediately comes to mind is a temporary exclusion or transfer with wage-level maintenance when the female employee learns that she is pregnant. This may not, however, really be an alternative if

247 See notes 238-40 supra \& accompanying text.

248 This could be accomplished not only by lowering the lead level in the work environment itself, but also by periodically removing workers who intend to have children. See note 169 supra \& accompanying text.

249 See notes 17-20 supra \& accompanying text.

250 See note 103 supra \& accompanying text.

251 See note 22 supra \& accompanying text. 
the danger to the fetus is substantial in the first few weeks after conception, as well might be the case.

In such circumstances, the only choice is to require the employer to lower the exposure levels to a point at which no signifcant teratogenic harm is threatened. If this only requires, for example, special respirators for female employees, then the court should hold that a less discriminatory alternative is available and hence, that the employer is in violation of title VII. If, on the other hand, expensive capital improvements would be necessary, a different conclusion may result-at least in the case of American Cyanamid. Evidence in the OSHA citation hearing for American Cyanamid's Willow Island, West Virginia plant suggested that a "technically feasible retrofit" of the plant to substantially reduce lead exposure levels in certain areas would cost the company about $\$ 2.6$ million. ${ }^{252}$ The administrative law judge adjudicating the case held this to be economically infeasible for this employer: ${ }^{283}$ evidence on the record showed that the lead chromate industry contracted at a rate of about ten percent per year; Willow Island's after-tax profits averaged $\$ 100,000$ per year with a return-on-equity of only one percent. ${ }^{254}$ Although the "unduly burdensome" standard posited in this Article is stricter than OSHA's feasibility test, it may well be that, given the large capital investment necessary relative to the low current and potential profit of the Willow Island plant, the plant clearly represents a case in which requiring the employer to reduce exposure levels further would be "unduly burdensome." Only under these circumstances would the employer's discriminatory policy be justified.

\section{CoNCLUSION}

The proposal outlined in this Article is an attempt to balance within the framework of existing law four powerful and competing interests: worker safety, equal employment opportunity, business profitability, and the well-being of future generations. In most cases, the balance will be struck in favor both of health and of equal employment opportunity; the courts should require employers to reduce the reproductive hazards associated with many manufacturing processes rather than allow them to circumvent the

252 Secretary of Labor v. American Cyanamid Co., OSHRC Docket No. 79-2438, at 18 (Aug. 20,1980).

253 Id. 21-22.

254 Id. 10. 
national policy of equality of employment opportunities. Only in the rarest instance will the interest in fetal health-and the proven inability of the employer to follow any policy but exclusion-compel the court to excuse otherwise inexcusable sex discrimination. This result will promote the interests of working men and womenand their unborn children-and serve to maintain the integrity of our developing law of equal opportunity. 